\title{
Safety assessment of corroded jacket platform considering decommissioning event
}

\author{
D.K. Kim ${ }^{1,2}$, M.A. Zalaya ${ }^{1,3}$, M.H. Mohd ${ }^{3}$, H.S. Choi ${ }^{2}$ and K.S. Park ${ }^{4 *}$ \\ ${ }^{1}$ Civil and Environmental Engineering Department, Universiti Teknologi PETRONAS, \\ 32610 Seri Iskandar, Perak, Malaysia \\ ${ }^{2}$ Graduate School of Engineering Mastership, \\ Pohang University of Science and Technology, 37673 Pohang, Republic of Korea \\ ${ }^{3}$ School of Ocean Engineering, Universiti Malaysia Terengganu, \\ 21300 Terengganu, Malaysia \\ ${ }^{4}$ Steel Structure Research Group, POSCO Global R\&D Centre, \\ 21985 Incheon, Republic of Korea \\ Email: dokim@ postech.ac.kr
}

\begin{abstract}
Continuous assessment of aged offshore structures is becoming extremely important to avoid any hazardous consequences throughout their design life. In Malaysian waters where most of the offshore structures are jacket platforms, it was found that many of these structures are currently operating beyond their design life. With continuous corrosion taking place, structural reliability and operation will be affected. Therefore, for the safety evaluation, this study focuses on the reassessment of an existing aged jacket platform in Malaysian waters pertaining to corrosion effect. In this study, pushover analysis was carried out to determine the ultimate strength of the corroded jacket platform by quantifying the reserve strength ratio value. Two different time-dependent corrosion wastage models were used in the present study to simulate the corrosion behaviour at the splash zone of the jacket platform. It was observed that average corrosion condition relatively simulated the calm waters of Malaysia and by applying this corrosion, the jacket platform can withstand the environmental load acting on it. The results developed in the present study will be useful for future study in predicting and modelling corrosion tolerance of jacket platforms in Malaysian waters.
\end{abstract}

Keywords: Pushover; ultimate strength; reserve strength ratio; ageing; decommissioning.

\section{INTRODUCTION}

The oil and gas industry has undergone an extremely rapid advancement of new technology as it has spread even to more remote and less accessible recourses. The number of offshore oil and gas installations is more than 6,500 units which are distributed to around 53 countries worldwide [1]. There are about 4,000 oil platforms in the Gulf of Mexico; 950 in Asia; 700 in the Middle East; 490 in Europe, the North Sea and North Atlantic, 380 in West Africa, and 340 in South America. Various types of offshore platforms have been installed but attention was particularly given to the fixed platforms. Each fixed platform was designed for the specific location, reservoir condition, water depth, soil characteristics, wind, wave, and current conditions. Furthermore, it is acknowledged that $95 \%$ of the offshore platforms in the world are jacket supported. There are more than 200 existing fixed offshore platforms operating in Malaysian waters [2]. 
These platforms are operated by various operators in three regions which are PMO, SKO, and SBO. The design life of these platforms is 30 years in accordance with the guidelines set forth as the PETRONAS Technical Standard [3]. In addition, it is stated that 90 platforms have exceeded their design life. It is expected that this number will increase up to $70-80 \%$ in the next five years. These platforms can be categorised as aged offshore structures and are subjected to hostile and corrosive marine environments. Throughout the service life of a fixed offshore platform, the strength capacity of the platform decreases gradually over the years due to environmental effects and accidental damages. The platform slowly degrades through corrosion and fatigue. Hostile and corrosive marine environments play a major role in reducing the strength capacity. From the oil and gas standpoint, corrosion has become a serious problem which leads to severe damage and structural failure and potentially leads to unsafe working conditions for operators. In view of the problem severity, operators conduct continuous reassessments on the aged platforms to monitor for maintenance and ensure a prolonged safe operation.

In order to reassess an existing offshore platform, actual uncertainties of the material and environmental loads need to be defined [4]. Material uncertainties may change after a certain time due to degradation particularly from fatigue and corrosion environment. Reassessments of fixed offshore platforms were conducted to determine the reliability and ultimate strength of existing platforms in Malaysian waters $[5,6]$. The current research provided a basic life extension study of aged fixed offshore platforms in Malaysia. Corrosion effect research on ships and offshore structures is continuously done over the years. Recently, the reassessment of offshore jacket structure caused by uniform corrosion damage was studied [7] and a research on corrosion effect on the structural reliability of steel offshore structures was carried out [8]. The corrosion effect damage on the ultimate strength of aged steel-plated marine structures was studied [9] as well. A study on the prediction of a corroded pipeline reliability considering corrosion damage was also done [10]. Fatigue reliability analysis of a jacket supported structure for offshore wind turbine considering corrosion effect had been studied [11]. A number of corrosion effect studies on ships and offshore structures were successfully performed. This study focused on the reassessment of an existing aged fixed offshore platform in Malaysian waters by considering time-dependent corrosion wastage effect. It is worth to note that there were two corrosion wastage models adopted in the study, which were from Paik et al. in 2003 [12] and the other corrosion model was proposed by the present study. A nonlinear pushover analysis was performed to determine the ultimate strength of the corroded structure by quantifying the Reserve Strength Ratio (RSR) value. Static analysis was carried out and the gravitational loads were first applied followed by an increase of environmental loads until the structure collapsed. The analysis was performed through a SACS finite element software [13]. The obtained outcome will be useful for the structural design, especially for assuming corrosion allowance of the offshore jacket which is planned to be installed in Malaysian waters.

\section{METHODS AND MATERIALS}

\section{Time-Dependent Corrosion Wastage Models}

Age-related degradations such as corrosion, localised dent, and fatigue cracking occurred in steel structures. In the case of offshore structures, a higher safety factor was considered from the beginning of the design stage to avoid any type of repair which may cause the operation to stop or reduce the production rate of oil and gas. It was hard to perfectly protect steel structures from the age-related damages, especially from corrosion. One of 
the influential factors among the time-dependent phenomenon was age-related degradation. Generally, age-related degradation such as corrosion, fatigue cracking, and localised dent occur during offshore operations. The corrosion phenomenon causes severe effects on the degradation of structural capacity, especially in terms of strength and fatigue performance. In addition, harsh environmental and operational conditions such as high temperature (HT), high pressure (HP), extreme wave, current, wind and many other factors in offshore fields may accelerate metal corrosion. In this regard, several methods were investigated to maintain the structural performance of offshore structures from corrosion damage. One good example is corrosion coating which is normally used in marine structures. In the case of corrosion types, a total of six corrosions were classified such as general, pitting, axial grooving, circumferential grooving, pinhole, axial slotting, and circumferential slotting corrosion[14]. The detecting technology for corrosion called the intelligent pigging system as a technical terminology in terms of its amount, location, and length has been developed to maintain the structural performance during the whole design life.

A number of studies were performed to figure out corrosion phenomenon which is a very complex process by Mother Nature and they have tried to create an estimation system for the corrosion depth by time to determine the corrosion coating thickness or corrosion addition thickness based on the obtained pigging data. With this regard, several types of researches were conducted using the corrosion modelling technique in terms of corrosion wastage model for ships and offshore structures [15-19]. The corrosion phenomenon was thoroughly investigated in marine environments in terms of effects of water velocity, dissolved oxygen, surface finish, water pollution, water velocity, and others [20-23]. Recently, an advanced technique was proposed for developing a timedependent corrosion wastage model by using the Weibull probability distribution function and¥ this method was applied to the ballast tank of ships [24]. Additionally, this technique was applied to the subsea gas pipeline to develop the time-dependent corrosion wastage model and the Anderson-Darling test was additionally used to find the well-fitted probability distribution function among six distribution functions such as Normal, Lognormal, Exponential, Weibull, 3-parameter Weibull, 2-parameter Exponential, and Gamma [25]. Finally, the 3-parameter Weibull distribution function was selected for developing the time-dependent corrosion wastage model of a gas pipeline. In the present study, simplified time-dependent corrosion damage models were proposed based on the obtained subsea pipeline pigging data in the shapes of 1) Linear, 2) Convex, and 3) Concave type [25].

\section{Corrosion Model}

Pitting corrosion is considered a general type of marine structure corrosion. Recently, with regards to pitting corrosion mechanism, various studies were performed [26-28]. Especially for the ship structures, researchers have proposed a method to build the timevariant corrosion wastage model which was verified by applying oil tankers [12]. In addition, the degradation of structural strength capacities was investigated by applying the above corrosion models for stiffened panel [29], hull girder [30-33], and FPSO [34]. An advanced method was proposed to predict corrosion depth by time and it was verified by applying to a ship ballast tank structure [24]. This technique was also applied to subsea well tube [35] and subsea gas pipeline [25] to establish the time-dependent corrosion wastage model, which can also provide a wide range of knowledge to understand nonlinear and complex corrosion behaviour. 


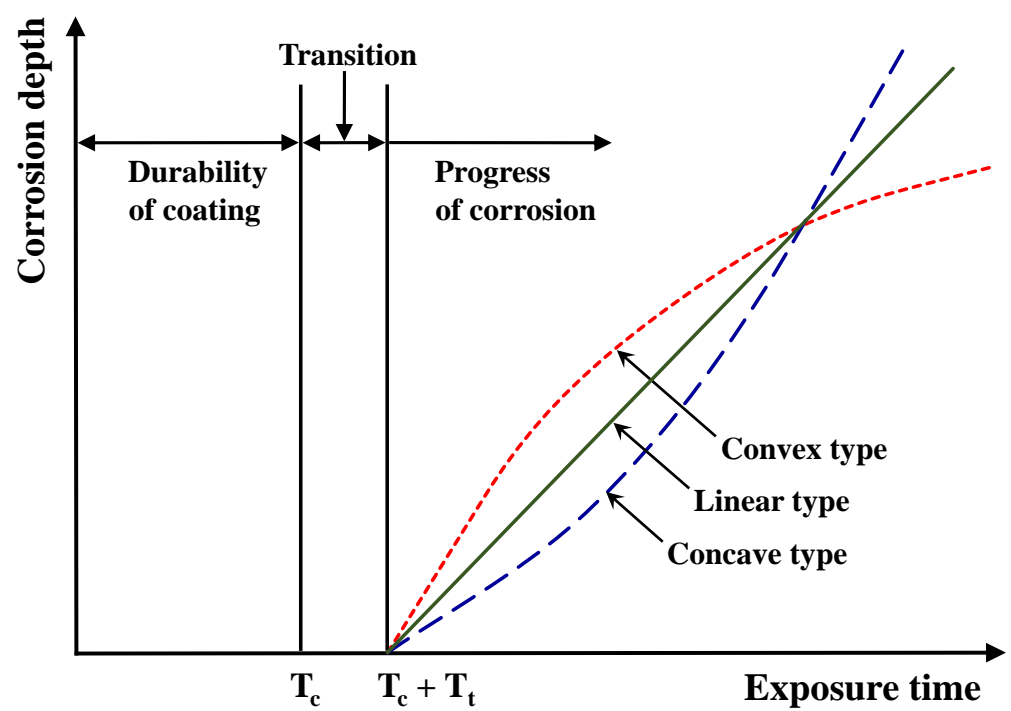

Figure 1. A mechanism of corrosion progress [36].

In order to propose the simplified time-variant corrosion wastage model, Paik's method was reviewed again as shown in Figure 1. This model shows the relationship between time and corrosion depth. As time goes by, structures are damaged by corrosion which means that the structural remaining strength may be decreased due to a reduction in thickness. Three (3) different stages were defined to explain the corrosion behaviour, such as durability of coating (or coating life) $\left(T_{c}\right)$, transition time $\left(T_{c}\right)$, and progress of corrosion. The amount of corrosion wastage by time was expressed by one of the famous formulas proposed as illustrated in Eq. (1)

$$
t_{r}=C_{1} T_{e}^{C_{2}}
$$

where, $t_{r}=$ corrosion depth, $T_{e}=$ exposure time in years after the breakdown of the coating $\left(=T-T_{c}-T_{t}\right), \quad T=$ exposure time in years, $T_{c}=$ coating life in years, $T_{t}=$ duration of transition in years, $C_{1}$ and $C_{2}=$ coefficients to be determined by statistical analysis of the pigging data.

The corrosion model was classified into three types, i.e., the Convex, Linear, and Concave types as presented in Figure 1. The trend of corrosion progress (the curve shape) was determined by the coefficients of $C_{2}$ as follows.

$$
\text { Corrosion model type }=\left\{\begin{array}{lll}
\text { Convex } & \text { for } & C_{2}<1 \\
\text { Linear } & \text { for } & C_{2}=1 \\
\text { Concave } & \text { for } & C_{2}>1
\end{array}\right.
$$

Figure 2 shows the time-dependent corrosion wastage models, i.e., average and severe cases with three (3) different coating lives such as 5.0, 7.5, and 10.0 years. This study aimed to investigate the effect of corrosion on the residual strength performance of offshore jacket structures, where the splash zone near the sea level and mostly suffered from corrosion damage, i.e., A/B-V and SSLB, was targeted. 


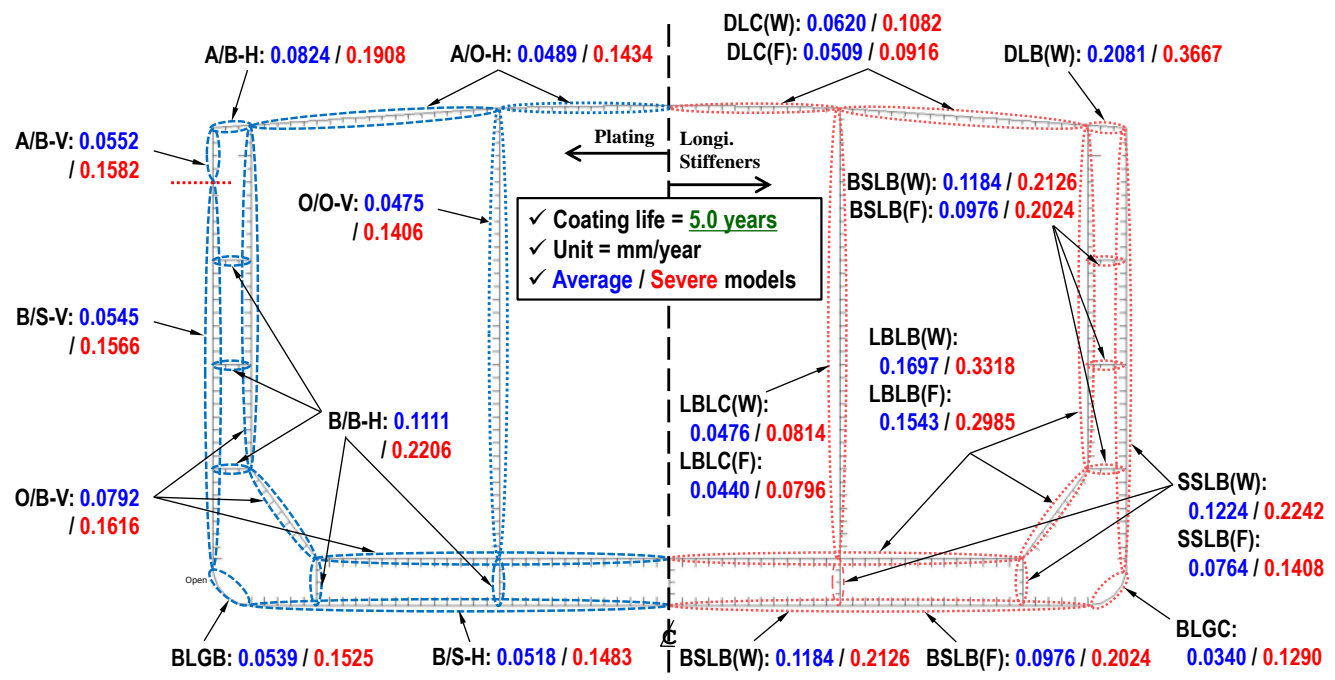

(a) Coating life $=5.0$ years

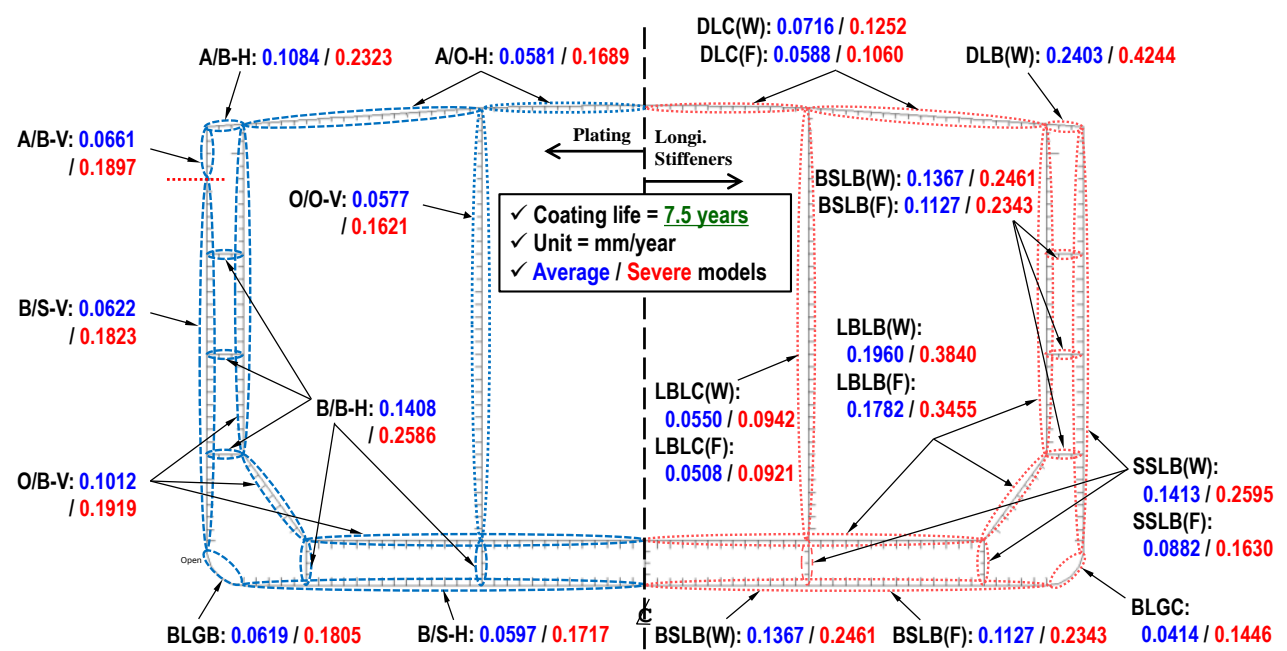

(b) Coating life $=7.5$ years

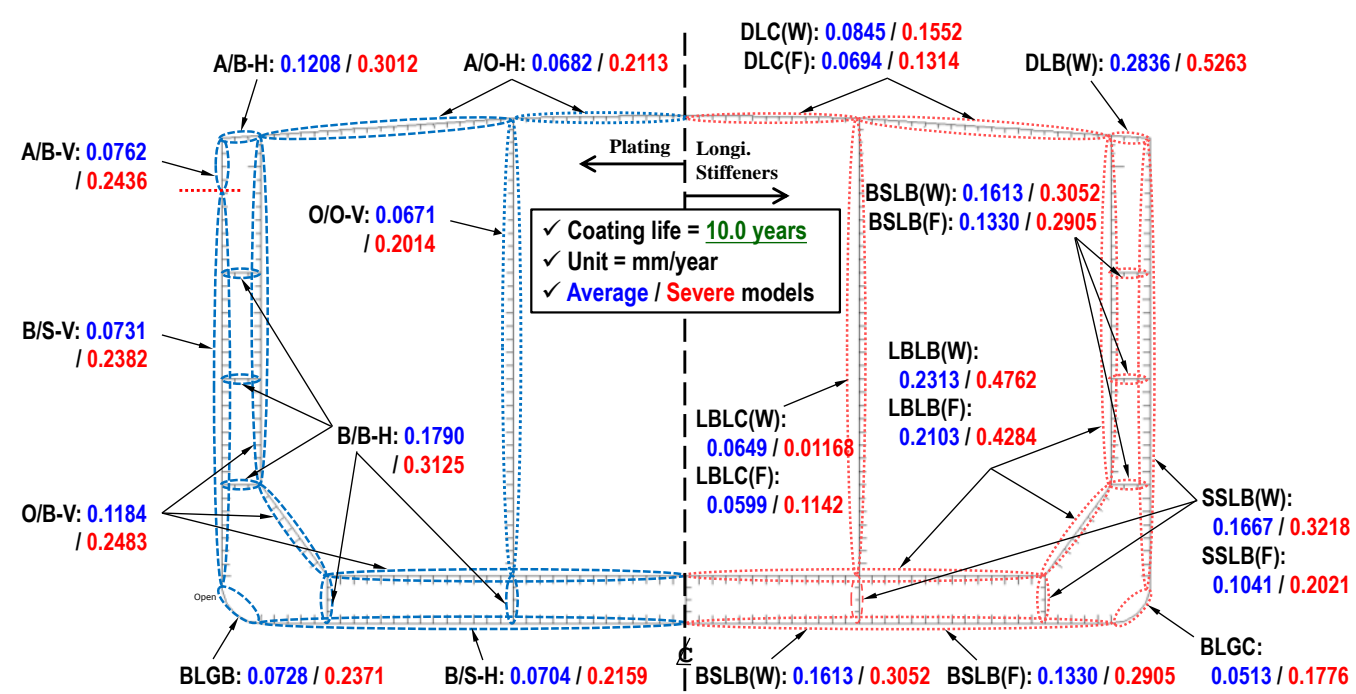

(c) Coating life $=10.0$ years

Figure 2. Time-dependent corrosion wastage model [12]. 


\section{Proposed Corrosion Model}

In this study, several types of corrosion data based on Eq. (2) were proposed for subsea pipelines. In a recent study, a corrosion model was applied to propose simplified corrosion models [25]. Four (4) different corrosion years of aged gas pipeline were adopted in the previous study, i.e., 8, 12, 19, and 29 years which were obtained from the pigging test. It is well known that the pigging test requires high cost and time. Therefore, only four (4) different corrosion years' data were collected. Figure 3 represents a schematic view of collected corrosion data by time and development of the time-variant corrosion wastage model. Basically, once corrosion data were collected, Goodness of fit test of corrosion data for each year was performed and normally, the Anderson-Darling test was applied. Then, the statistical analysis of the corrosion data for each year was conducted. At this stage, the mean and COV values must be calculated and compared to find the best-fit interval, which was chosen at a maximum mean and minimum COV. The next step was the formulation of the best-fit corrosion function. In a previous study, the 3-parameter Weibull distribution functions, including location, shape, and scale parameters were applied to develop the corrosion model of gas pipeline. Finally, the time-variant corrosion model was proposed. The difference between the method proposed and previous approaches was that the relationship between each coefficient, i.e., location, shape, and scale parameter, and time was formulated [24].

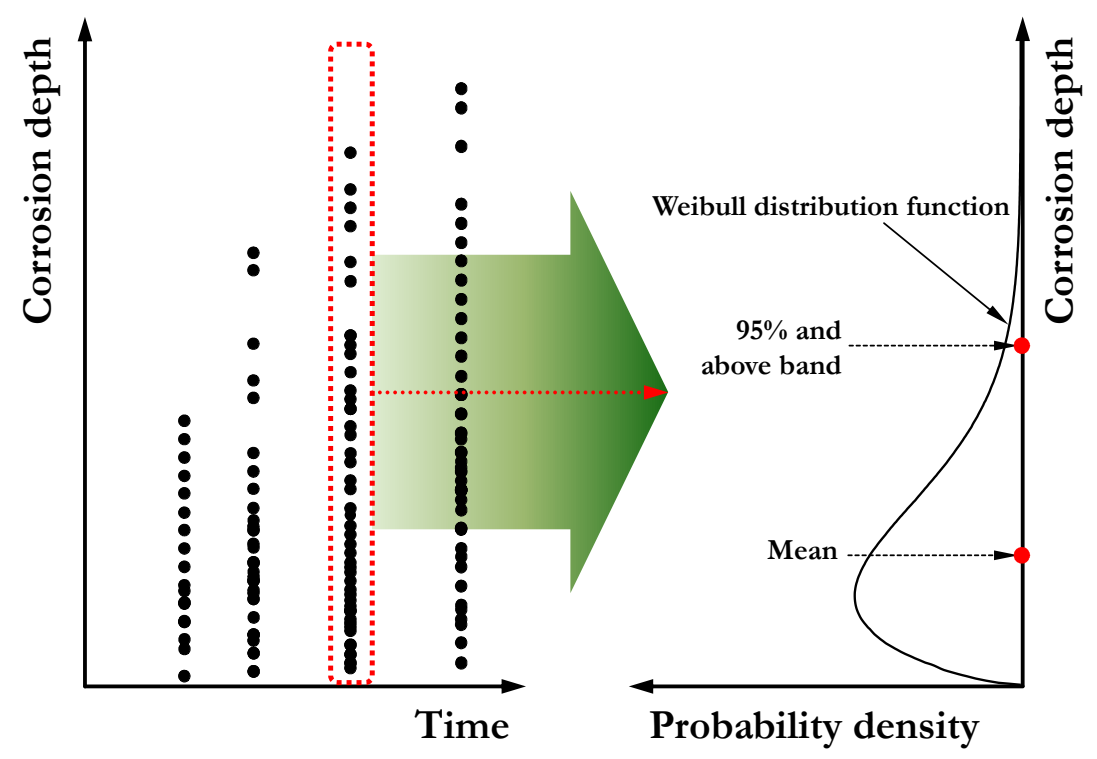

Figure 3. Schematic illustration of mean (average) and 95\% and above band (severe).

Figure 4 shows the collected corrosion data of gas pipeline. Throughout the previous research, Eqs. (3a-d) were proposed [25].

$$
f_{c_{r}}=\frac{\alpha}{\beta}\left(\frac{T_{e}-\gamma}{\beta}\right)^{\alpha-1} \cdot \exp \left[-\left(\frac{T_{e}-\gamma}{\beta}\right)^{\alpha}\right]
$$

where $f_{c_{r}}=$ function of corrosion depth, $\alpha=$ shape parameter, $\beta=$ scale parameter, $\gamma$ = location parameter. 


$$
\begin{aligned}
\alpha & =\left\{\begin{array}{l}
0.003337 T_{e}-0.130420 T_{e}+2.4557 \text { for mean (average) } \\
0.004795 T_{e}-0.172193 T_{e}+2.3957 \text { for } 95 \% \text { \& above }(\text { severe) }
\end{array}\right. \\
\beta & =\left\{\begin{array}{l}
-0.000997 T_{e}+0.013425 T_{e}+1.58201 \text { for mean (average) } \\
0.007892 T_{e}-0.223267 T_{e}+2.768088 \text { for } 95 \% \text { \& above (severe) }
\end{array}\right. \\
\gamma & =\left\{\begin{array}{l}
0.0003455 T_{e}+0.062137 T_{e}-0.365129 \text { for mean (average) } \\
-0.010737 T_{e}+0.411525 T_{e}+0.692169 \text { for } 95 \% \text { \& above (severe) }
\end{array}\right.
\end{aligned}
$$

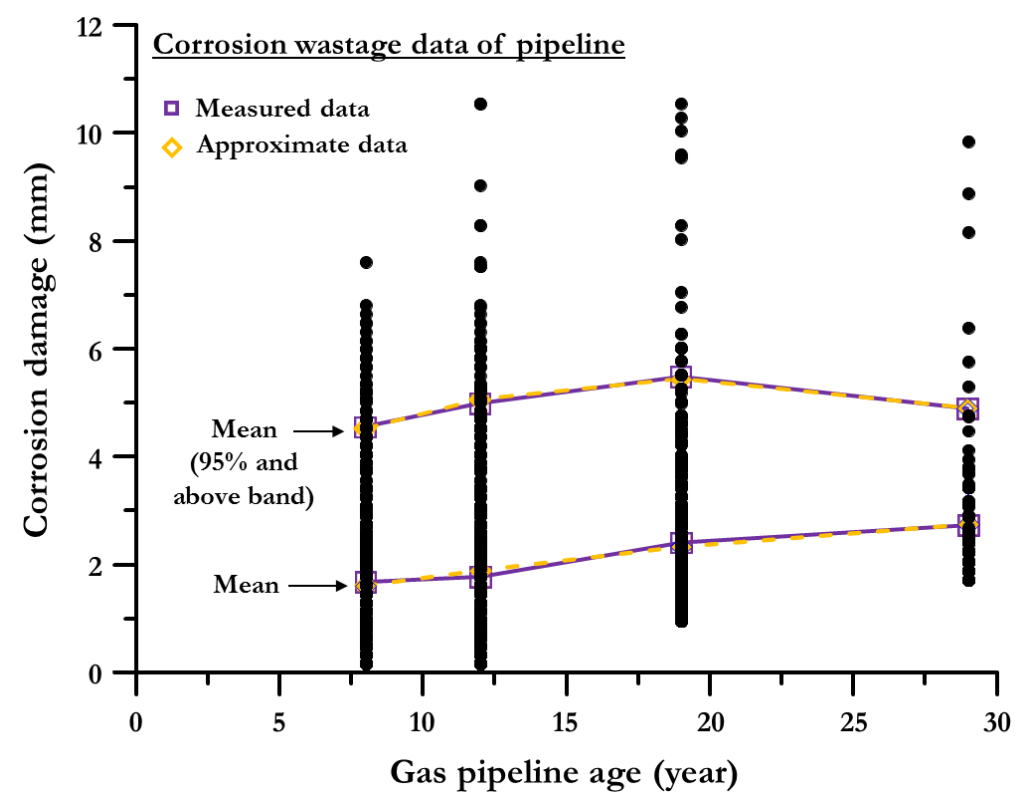

Figure 4. Time-variant corrosion wastage model for gas pipeline [25]

The obtained mean and $95 \%$ and above band data for the measured and approximate values are presented in Table 1 respectively. Here, the approximate values represent the modified outcome throughout the proposed technique by [24]. By applying the approximate values, a smooth shape of the corrosion model was developed. Figure 5 represents the curve fitting of the time-variant corrosion wastage model as a shape of Eq. (1). A proposed time-variant corrosion in the shape of Eq. (1) with five (5) different $\mathrm{C}_{2}$ coefficients such as $0.5,0.8,1.0,1.2$, and 1.5 is shown in Eq. (2) [12]. They proposed in Eq. (1) that $T_{c}$ is a constant parameter as a corrosion coating life which was assumed as 5, 7.5, and 10 years. In Figure 5, only 5 years of corrosion coating life were assumed. In the case of $C_{1}$, it was determined by the statistical analysis in terms of mean and coefficient of variation (COV). A statistical analysis was performed and the obtained results are given in Table 1 [25].

From the data in Table 1, the time-variant corrosion wastage models by applying measured and approximate data were plotted in Figures 5(a-d). It was shown that a similar trend was observed from two different data, i.e., measured and approximated. More smooth curves were obtained by applying approximate corrosion data. In the case of subsea gas pipeline structures, the Convex type presented in Figure 1 represents the behaviour of corrosion progress. In addition, 0.3 of $C_{2}$ value was applied for the curvefitting with other $\mathrm{C}_{2}$ values, i.e., 0.5, 0.8, 1.0, 1.2, and 1.5, were recommended [12]. 
Table 1. Data for the development of corrosion model [25].

\begin{tabular}{lllllllllll}
\hline $\begin{array}{l}\text { Age } \\
\text { (yrs) }\end{array}$ & \multicolumn{3}{l}{ Measured $(\mathrm{mm})$} & \multicolumn{10}{c}{ Approximate $(\mathrm{mm})$} \\
\cline { 2 - 12 } & Mean & $\begin{array}{l}\text { Mean } \\
+ \text { SD }\end{array}$ & $\begin{array}{l}\text { Mean } \\
+ \text { 2SD }\end{array}$ & $\begin{array}{l}\text { Mean } \\
+ \text { 3SD }\end{array}$ & $\begin{array}{l}\geq 95 \% \\
\text { band }\end{array}$ & $\begin{array}{l}\text { Mean } \\
(\mathrm{mm})\end{array}$ & $\begin{array}{l}\text { Mean } \\
+ \text { SD }\end{array}$ & $\begin{array}{l}\text { Mean } \\
+2 S D\end{array}$ & $\begin{array}{l}\text { Mean } \\
+3 S D\end{array}$ & $\begin{array}{l}\geq 95 \% \\
\text { band }\end{array}$ \\
\hline 8.0 & 1.674 & 2.575 & 3.476 & 4.377 & 4.529 & 1.610 & 2.528 & 3.446 & 4.364 & 4.494 \\
12.0 & 1.772 & 2.900 & 4.028 & 5.156 & 4.966 & 1.893 & 2.973 & 4.053 & 5.133 & 5.037 \\
19.0 & 2.407 & 3.353 & 4.699 & 5.845 & 5.458 & 2.335 & 3.519 & 4.703 & 5.887 & 5.416 \\
29.0 & 2.735 & 3.444 & 4.153 & 4.862 & 4.869 & 2.752 & 3.456 & 4.160 & 4.864 & 4.876 \\
\hline
\end{tabular}

Note: $\mathrm{SD}=$ standard deviation

The obtained empirical formulas by using the mean and $95 \%$ and above band data for the prediction of time-variant corrosion wastage shown in Figure 5 and in Eqs. (4-5).

\section{For mean value (Average model)}

$$
t_{r(\text { measured })}=\left\{\begin{array}{l}
1.0169 \cdot(T-5)^{0.3} \\
0.6248 \cdot(T-5)^{0.5} \\
0.2599 \cdot(T-5)^{0.8} \\
0.1407 \cdot(T-5)^{1.0} \\
0.0751 \cdot(T-5)^{1.2} \\
0.0289 \cdot(T-5)^{1.5}
\end{array} \quad ; t_{r(\text { (approximate })}=\left\{\begin{array}{l}
1.0170 \cdot(T-5)^{0.3} \\
0.6253 \cdot(T-5)^{0.5} \\
0.2601 \cdot(T-5)^{0.8} \\
0.1407 \cdot(T-5)^{1.0} \\
0.0751 \cdot(T-5)^{1.2} \\
0.0289 \cdot(T-5)^{1.5}
\end{array}\right.\right.
$$

\section{For $95 \%$ and above band value (Severe model)}

$$
t_{r(\text { measured })}=\left\{\begin{array}{l}
2.7195 \cdot(T-5)^{0.3} \\
1.7250 \cdot(T-5)^{0.5} \\
0.8242 \cdot(T-5)^{0.8} \\
0.4912 \cdot(T-5)^{1.0} \\
0.2895 \cdot(T-5)^{1.2} \\
0.1289 \cdot(T-5)^{1.5}
\end{array} ; t_{r(\text { approximate })}=\left\{\begin{array}{l}
2.7181 \cdot(T-5)^{0.3} \\
1.7240 \cdot(T-5)^{0.5} \\
0.8232 \cdot(T-5)^{0.8} \\
0.4904 \cdot(T-5)^{1.0} \\
0.2886 \cdot(T-5)^{1.2} \\
0.1286 \cdot(T-5)^{1.5}
\end{array}\right.\right.
$$

It was found that 0.3 of the $C_{2}$ value was well-fitted with the pitting corrosion phenomenon of the gas pipeline $\left(R^{2}=0.95\right.$ to 0.99$)$ presented in Figure 5. In the case of $R^{2}$ values, they tend to be inversely proportional to the $C_{2}$ values. On the other hand, other $C_{2}$ values such as $0.5,0.8,1.0,1.2$, and 1.5 were not recommended to be used in practice except for the $C_{2}=0.3$ case. In order to get the accurate time-variant corrosion wastage model for gas pipeline, various exposure times in years after the breakdown of the coating $\left(T_{e}\right)$ and various corrosion data, i.e., Mean, Mean + Standard Deviation (S.D.), Mean + 2S.D., and $95 \%$ and above by the probabilistic approach were considered. Here, $T_{e}$ is defined and calculated as $T_{e}=T-T_{c}-T_{t}$ where $T=$ exposure time in years, $T_{c}$ $=$ coating life in years, $T_{t}=$ duration of transition in years. In addition, five different exposure times were assumed such as 1, 2, 3, 4, and 5 years as presented in Appendix (Eqs. A1-A5 and Figure A1. From the obtained time-variant corrosion wastage models in Eq. (A1), simple and direct estimation of corrosion behaviour can be performed. It is well recognised that pitting is one of the representative phenomena of corrosion type. It is natural for the occurrence of corrosion damage in steel structures, i.e., ship, offshore, and subsea structures, as time goes on. In the case of subsea pipeline, maintenance or repair 
would require a severe loss of production as well as time. In addition, the inspection of subsea pipeline, which is normally performed by the pigging tool, is a time-consuming and expensive job. In this regard, the time-variant corrosion wastage model for pipeline was needed for the estimation of corrosion damage growth.
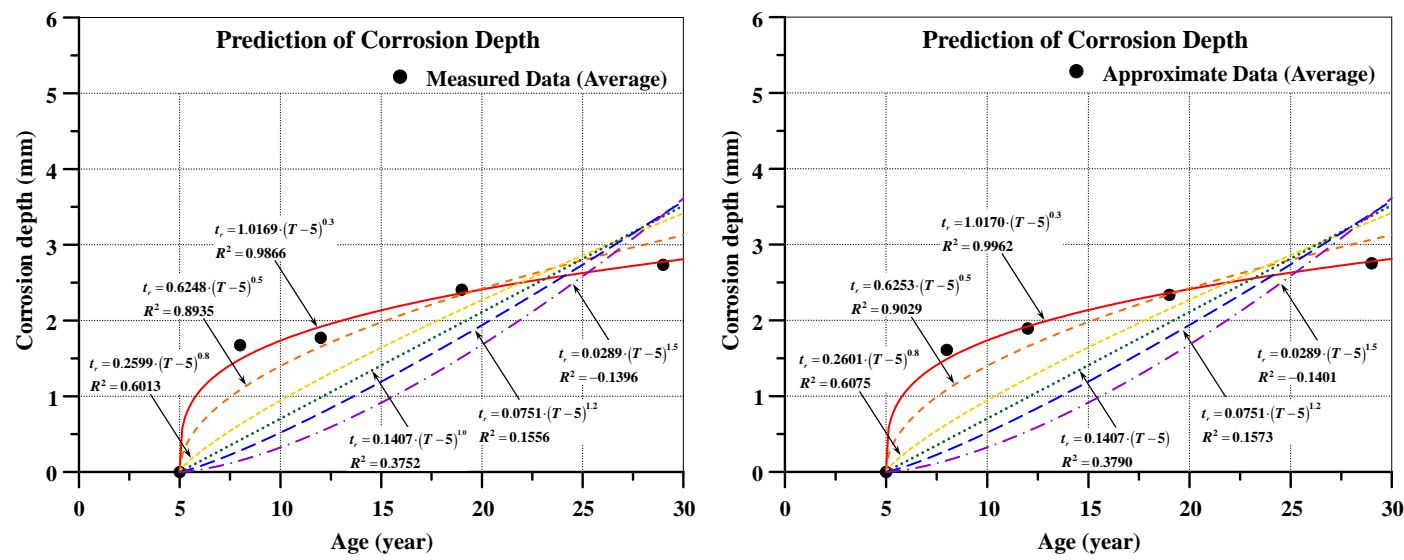

(a) Average model based on measured data; (b) average model based on approximate data
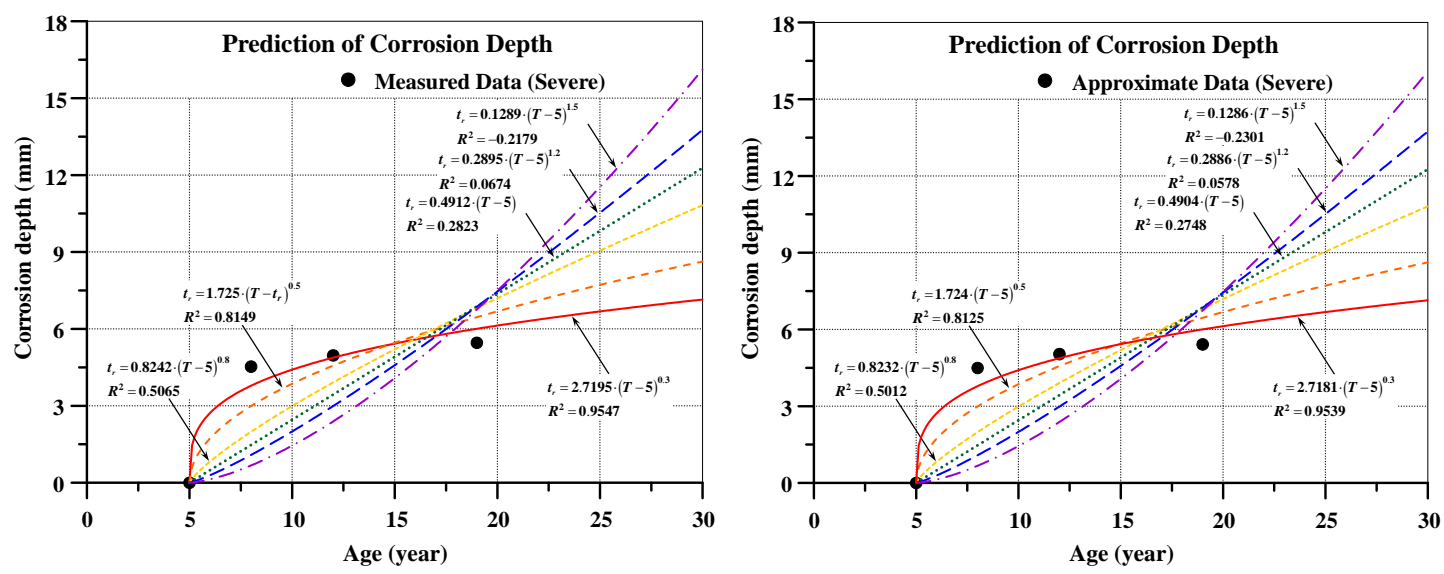

(c) Severe model based on measured data;

(d) Severe model based on approximate data

Figure 5. Time-variant corrosion wastage model for gas pipeline by applying Eq. (1).

The assumptions and obtained outcomes from the present study can be summarised as follows.

i) Three types of prediction models which are Convex, Concave, and Linear were applied to estimate corrosion progress. In the case of subsea gas pipeline structure, the Convex model was well fitted.

ii) In order to obtain a more accurate result, four different types of time-variant corrosion wastage models, i.e., by applying Mean value, Mean + Standard Deviation (S.D.) value, Mean +2 S.D. value, and the $95 \%$ and above value were proposed based on the Convex model.

iii) Various exposure times after breakdown of the coating $\left(T_{e}\right)$ were assumed to propose the time-variant corrosion wastage model such as $T_{e}=1,2,3,4$, and 5 years.

iv) For a smooth curve fitting, measured and approximate corrosion data were used to propose the time-variant corrosion wastage model. 


\section{Modelling of Aged Fixed Jacket Platform}

Structural modelling

An existing fixed platform shown in Figure 6 was the subject of this study. Platform A was a living quarter installed at 63.148 metres of water depth. The fixed offshore platform was a four-legged platform with four piles which penetrated 86.5 metres deep below the mudline. The piles were not shown in Figure 6 but included in the analyses. The platform included two plan levels which were cellar deck and main deck. The main deck included a bridge support on the southwest corner and supported the main accommodation module and a helideck structure stacked on top of the other. The cellar deck supported the bulk of the platform equipment. It had one (1) boat landing and sixty (60) anodes installed. The platform was modelled as a three-dimensional space frame made up of beam-column finite elements. The jacket part had four bays and all tubular members and joints were designed in accordance with API RP2A-WSD. Minor commands were introduced in the model file for pushover analysis and modifications of the member properties were made to simulate the corrosion behaviour.

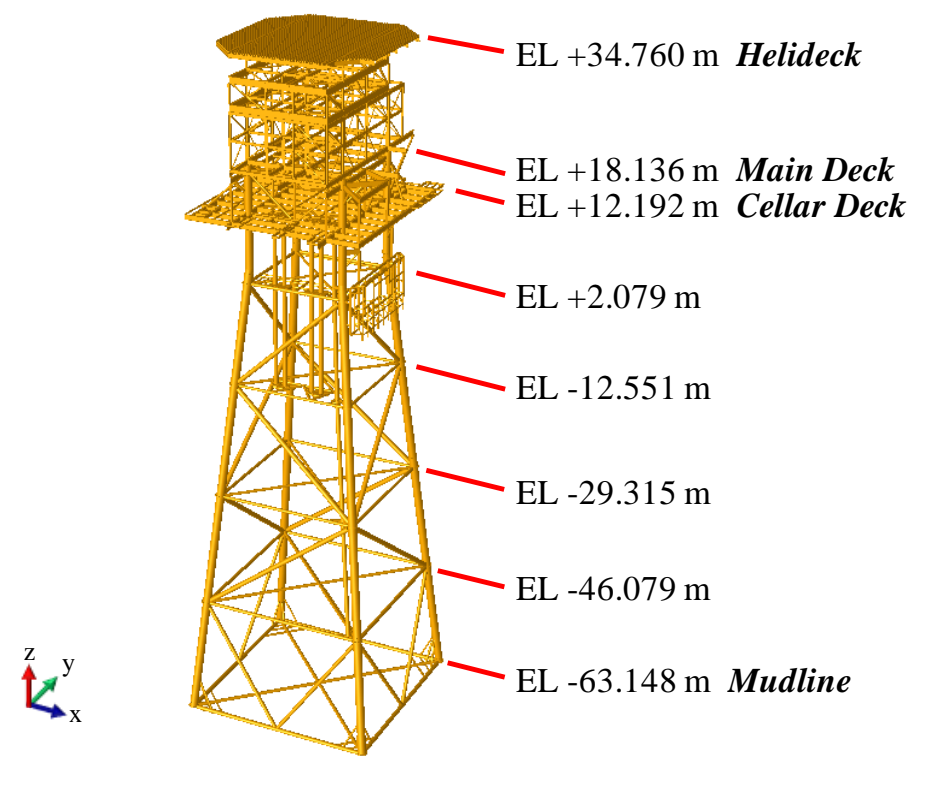

Figure 6. 3-Dimensional view of Platform A.

\section{Gravity Loads}

The dead and live loads of the platform were retained as per design basis. Loads included in this study based on Table 2 .

Table 2. Gravitational load.

\begin{tabular}{ll}
\hline \multicolumn{1}{c}{ Dead Load } & \multicolumn{1}{c}{ Live Load } \\
\hline SACS generated self-weight & Jacket walkway live load \\
Jacket miscellaneous weight & Accommodation module lower level live load \\
Topside miscellaneous weight & Accommodation module upper-level live load \\
Equipment weight & Top accommodation module live load \\
Portable water tank weight & Helideck live load \\
Piping weight & Helicopter live load \\
\hline
\end{tabular}




\section{Environmental Loads}

The environmental loading impact on the platform considered eight $(8)$ directions $\left(0^{\circ}\right.$, $45^{\circ}, 90^{\circ}, 135^{\circ}, 180^{\circ}, 249^{\circ}, 270^{\circ}$ and $315^{\circ}$ ) and it was found that $270^{\circ}$ was a critical direction for the platform, which will be explained later. Storm condition was applied to the platform according to the metocean data as the maximum load acting on the structure. Metocean data which was assumed as 100-year period data, as shown in Tables 3-4, were applied during analysis. A maximum water depth of 61.848 metres was used for the 100year storm condition.

Table 3. Wave load.

\begin{tabular}{lcccccccc}
\hline \multirow{2}{*}{ Wave Parameter } & \multicolumn{7}{c}{100 -year Directional Wave } \\
\cline { 2 - 8 } & $0^{\circ}$ & $45^{\circ}$ & $90^{\circ}$ & $135^{\circ}$ & $180^{\circ}$ & $249^{\circ}$ & $270^{\circ}$ & $315^{\circ}$ \\
$\mathrm{H}_{\max }(\mathrm{m})$ & 10.20 & 12.1 & 10.2 & 5.4 & 5.4 & 5.4 & 10.2 & 12.1 \\
$\mathrm{~T}_{\text {ass }}(\mathrm{s})$ & 8.90 & 9.4 & 8.9 & 8.9 & 8.9 & 8.9 & 8.9 & 9.4 \\
\hline
\end{tabular}

Table 4. Current load.

\begin{tabular}{ccccccccc}
\hline \multirow{2}{*}{ Depth $(\mathrm{m})$} & \multicolumn{8}{c}{ 100-year Directional Current } \\
\cline { 2 - 9 } & $0^{\circ}$ & $45^{\circ}$ & $90^{\circ}$ & $135^{\circ}$ & $180^{\circ}$ & $225^{\circ}$ & $270^{\circ}$ & $315^{\circ}$ \\
\hline 61.848 & 0.690 & 0.960 & 1.050 & 0.710 & 0.620 & 1.090 & 2.230 & 0.910 \\
46.386 & 0.630 & 0.870 & 0.950 & 0.650 & 0.560 & 0.990 & 2.030 & 0.830 \\
30.924 & 0.550 & 0.760 & 0.830 & 0.560 & 0.490 & 0.870 & 1.770 & 0.720 \\
15.462 & 0.430 & 0.610 & 0.660 & 0.450 & 0.390 & 0.690 & 1.410 & 0.570 \\
3.092 & 0.250 & 0.350 & 0.390 & 0.260 & 0.230 & 0.400 & 0.820 & 0.340 \\
\hline
\end{tabular}

For the purpose of illustration, the environmental loading at $270^{\circ}$ together with the drag coefficient, $C_{d}$ and mass coefficient, $C_{m}$ are illustrated in Figure 7.

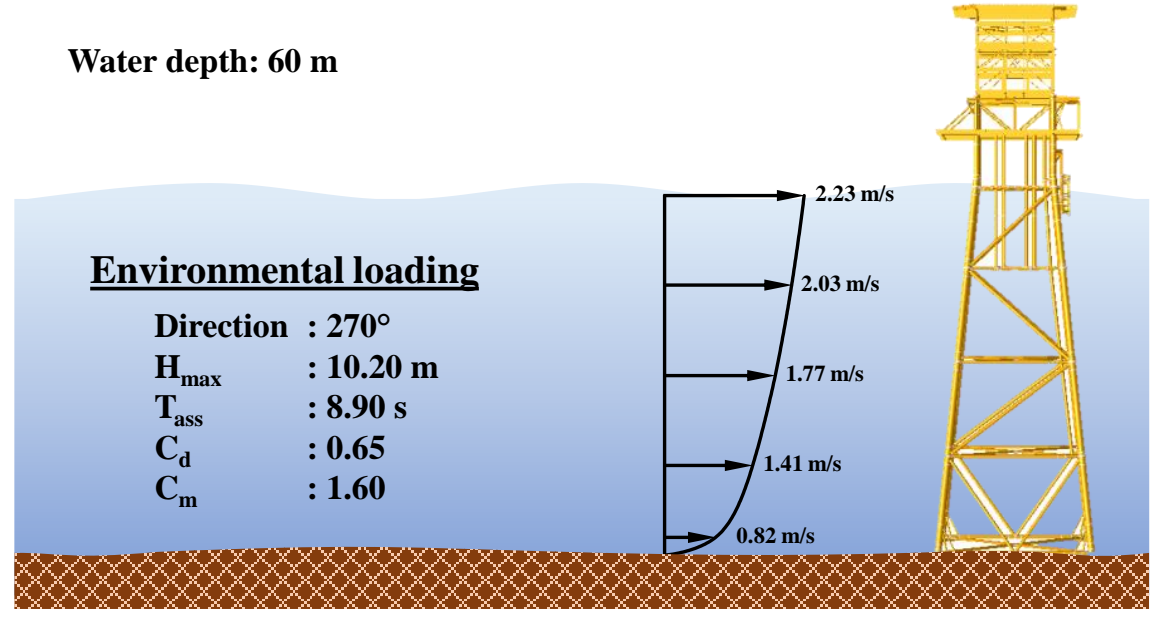

Figure 7. Environmental loading acting on the structure.

\section{Marine Growth}

In this study, marine growth profile in Table 5 was used in the analysis as an underwater inspection report. It was important to include the marine growth in the analysis as it increased the diameter of the jacket member, thus simulating the actual condition. 
Table 5. Marine growth

\begin{tabular}{rrr}
\hline \multicolumn{2}{c}{ Depth (m) } & $\begin{array}{c}\text { Marine Growth } \\
\text { Average Thickness (mm) }\end{array}$ \\
\cline { 1 - 2 } From & \multicolumn{1}{c}{ To } & \\
\hline 0.000 & 3.148 & 16.3 \\
3.148 & 10.000 & 16.3 \\
10.000 & 15.000 & 29.6 \\
15.000 & 20.000 & 29.6 \\
20.000 & 25.000 & 31.7 \\
25.000 & 30.000 & 31.7 \\
30.000 & 35.000 & 30.1 \\
35.000 & 40.000 & 28.0 \\
40.000 & 50.000 & 31.2 \\
45.000 & 55.000 & 42.9 \\
50.000 & 55.000 & 78.3 \\
55.000 & 60.000 & 70.3 \\
60.000 & 63.148 & 72.2 \\
\hline
\end{tabular}

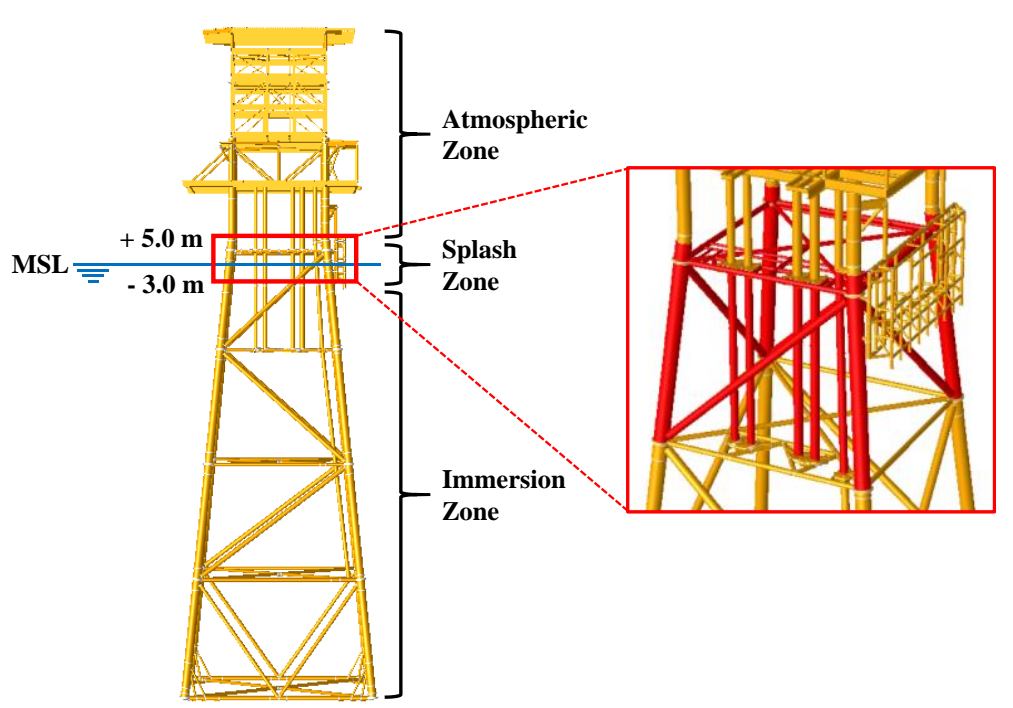

Figure 8. Splash zone area with corroded members.

\section{Application of Time-Dependent Corrosion Model}

There are different corrosion rates acting on an offshore platform that could be divided into three parts, which are at the atmospheric zone, splash zone, and immersion zone. In this present study, the platform was assumed to be having corrosion at the splash zone area as shown in Figure 8. Uniform corrosion, which is one of the general types of corrosion, was assumed and applied in the splash zone where it equally reduced the wall thickness of each member. A number of studies were conducted for the condition assessment (or health monitoring) of aged structures. Corrosion, fatigue cracking, and localised dent were the most important factors to be considered in the ageing effect. In the case of corrosion damage, pitting corrosion pattern was mostly observed in offshore and ocean structures. However, uniform corrosion was still generally adopted for the numerical modelling of corroded structure rather than pitting corrosion. This was because pitting corrosion modelling took additional modelling cost and effort including 
uncertainties of corrosion location and nonlinearities. If the structural geometry or shape was simple such as plate element, pitting corrosion may be considered for the numerical modelling. Of course, pitting corrosion modelling was recommended to get accurate results. In the case of whole structural modelling, uniform corrosion may give some advantages to saving computational cost. With regards to uniform corrosion, several application studies were performed for ship hull girders in normal conditions, accidental conditions, and low-temperature conditions [36-38]

The present study focused on the effect of corrosion damage on the ultimate strength performance of a fixed platform by utilising pushover (=collapse) analysis. Two (2) different corrosion models and different corrosion levels (severe and average) were investigated. Two different time-dependent corrosion wastage models that were used in the numerical simulation are summarised in Table 5, obtained from Eqs. (6-7). An equation to determine corrosion depth by adopting the linear type was formulated, which is shown in Eqs. (6-7), which was the value of SSLB(W) as illustrated in Figure 2(a) [12].

Corrosion model by Paik et al. [12]

$$
\begin{array}{ll}
t_{d}=0.1224 \cdot(T-5.0)^{1.0} & \text { for Average case } \\
t_{d}=0.2242 \cdot(T-5.0)^{1.0} & \text { for Severe case }
\end{array}
$$

\section{Present proposed Corrosion model}

$$
\begin{array}{ll}
t_{d}=1.0170 \cdot(T-5.0)^{0.3} & \text { for Average case } \\
t_{d}=2.7181 \cdot(T-5.0)^{0.3} & \text { for Severe case }
\end{array}
$$

In this study, advanced time-dependent corrosion models by adopting the Convex type as shown in Eq. 7 were proposed. Both corrosion wastage models used in this study are presented in Figure 9.

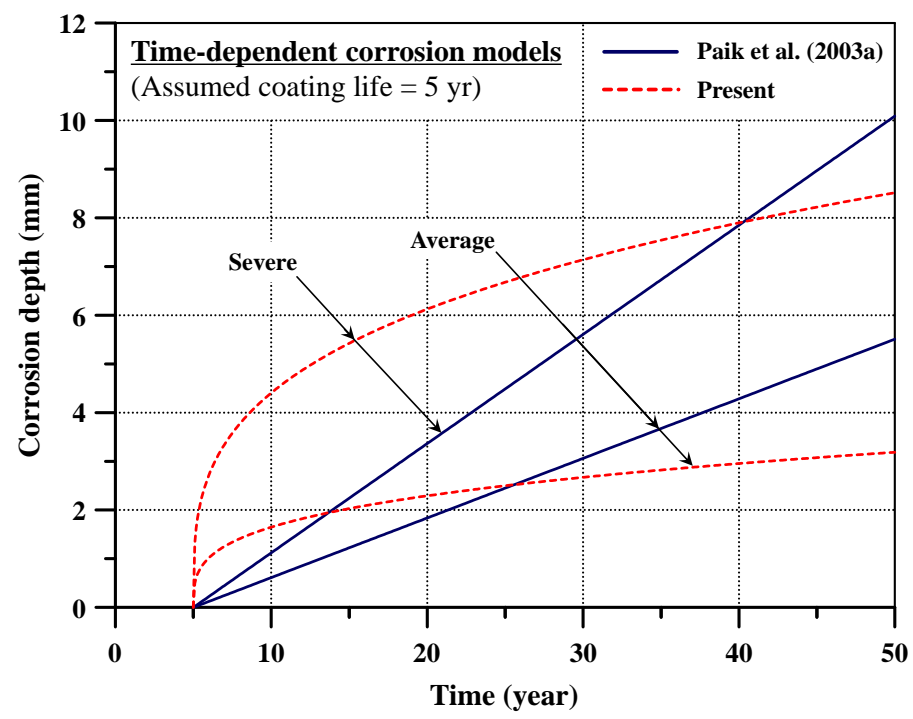

Figure 9. Time-dependent corrosion wastage models.

Table 6 shows the applied corrosion depth data for the numerical simulation of aged fixed jacket platform. Corrosion damage will start to occur after year 5 because the 
coating life was assumed as 5 years. The modification to apply uniform corrosion damage was then made to the structure according to the corrosion data and simulation cases.

Table 6. Selected corrosion data for the numerical simulation.

\begin{tabular}{ccccc}
\hline & \multicolumn{4}{c}{ Corrosion depth (mm) } \\
\cline { 2 - 5 } Year & Paik et al. [12] & Present study \\
\cline { 2 - 5 } & Average & Severe & Average & Severe \\
\hline 5 & 0.000 & 0.000 & 0.000 & 0.000 \\
10 & 0.612 & 1.121 & 1.648 & 4.405 \\
15 & 1.224 & 2.242 & 2.029 & 5.423 \\
20 & 1.836 & 3.363 & 2.292 & 6.125 \\
25 & 2.448 & 4.484 & 2.498 & 6.677 \\
30 & 3.060 & 5.605 & 2.671 & 7.139 \\
35 & 3.672 & 6.726 & 2.821 & 7.541 \\
40 & 4.284 & 7.847 & 2.955 & 7.897 \\
45 & 4.896 & 8.968 & 3.076 & 8.220 \\
50 & 5.508 & 10.089 & 3.186 & 8.516 \\
\hline
\end{tabular}

\section{Collapse or Pushover Analysis of Aged Fixed Jacket Platform}

Static pushover is a common analysis used in assessing the reliability of fixed offshore platforms. It is widely used in current offshore standards to evaluate nonlinear behaviour and ultimate capacity of offshore platforms against environmental wave loading [39]. The pushover analysis literally consists of a representative snapshot of lateral wave forces acting on the platform structure [40]. Vertical operating load and lateral extreme storm load are required to execute pushover analysis under extreme storm conditions. The vertical load is transferred from the deck to the jacket and acts as a constant load, which includes dead loads that are made up of self-weight plus equipment weights on the deck, and live loads. The lateral load is the load that would push the structure to its ultimate capacity. In this study, the pushover analysis was conducted for Platform A. The dead and live loads of the platform were retained as per the design basis. As mentioned earlier, a finite element software, SACS was used in this study.

\section{Reserve Strength Ratio}

Based on the output from pushover analysis, RSR can be determined as an approach to examine the ultimate strength of the platform. The serve strength ratio (RSR) can be defined as:

$$
R S R=\frac{\text { Ultimate Collapse Load }}{100 y \text { r Design Load Condition }}
$$

The RSR was the ratio of the platform's ultimate lateral load carrying capacity to its 100-year environmental loading [41]. Minimum RSR was found to be at $270^{\circ}$ of the platform. Detailed results of the pushover analysis to determine the minimum RSR are shown in Figure 10. Based on this result, $270^{\circ}$ was selected to apply the 100 -year environmental loading with corrosion taking place at the splash zone. 


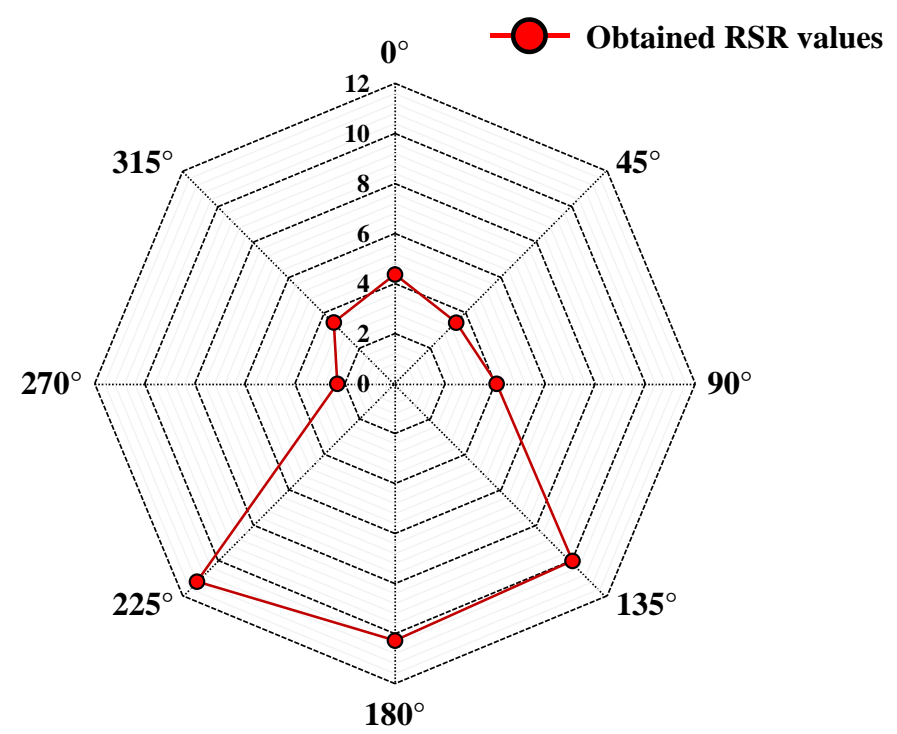

Figure 10. Distributed RSR with as-built condition.

Based on the analyses, the RSR value gradually decreased from year 5 to year 50 for both corrosion conditions. These values were then compared to the PCSB Structural Integrity and Inspection Analyses of Ageing Jackets Reassessment Basis [42]. As stated in the guideline,

"In order to apply the simplified structural reliability analysis, the derived RSR should be greater than 1.32 for unmanned platform and 1.50 for manned platform." [43]

RSR value of 1.50 should be adopted in this study because Platform A was a manned platform. As shown in Figure 11(a), where average corrosion condition was applied, the lowest RSR was at year 50 which was above the acceptable value of 1.50. It had an RSR value of 2.03 for Paik's model and 2.20 for Kim's model. Hence, it is safe to mention that this Platform A was safe to be operational up to 50 years with average corrosion taking place. It should be noted that this assumption was not considering any other possible hazards such as accidental damages and pile related failures. In this study, it was observed that the average corrosion condition relatively simulated the calm waters of Malaysia where the environmental condition is much safer compared to the North Sea region or the Gulf of Mexico[44].

\section{Analysis Results}

On the other hand, the RSR values started to decrease below the acceptable value of 1.50 after around 35 years when severe corrosion condition was applied to the platform. The results are illustrated in Figure 11(a). In fact, after 35 years, it was observed that the platform could not resist the gravitational load acting on the platform which resulted in the RSR decreasing to nearly zero (0). In addition, it was observed that 35.3 and 36.4 years were selected to be a safe limit when Kim and Paik's time-dependent severe corrosion wastage models were applied based on PTS guidelines (PTS 2012). Both corrosion models showed a similar trend after 35 years which meant that the platform was no longer safe to be operational if severe corrosion occurred. PTS guidelines can predict well the structural condition damage by time-dependent corrosion. In this study, the 
thickness of each corroded member in the splash zone area was reduced to account for corrosion. The average thickness reduction ratio was as illustrated in Figure 11(b). By using Paik's average corrosion model which was a linear thickness reduction, it was observed that the RSR value decreased almost similarly to the linear trend of thickness reduction. Besides that, the RSR decrement in Kim's average corrosion model also showed an almost similar trend in the thickness reduction ratio. Different from both severe corrosion models by Paik and Kim, it was observed that the RSR value had decreased quite consistently up to 35 years before the RSR dropped to nearly beyond zero (0). This was because, when the severe uniform corrosion was applied, critical members of the splash zone also experienced the same amount of thickness reduction with the other members. The remaining thickness was very small, resulting in the member's failure and led to the collapse of the platform.
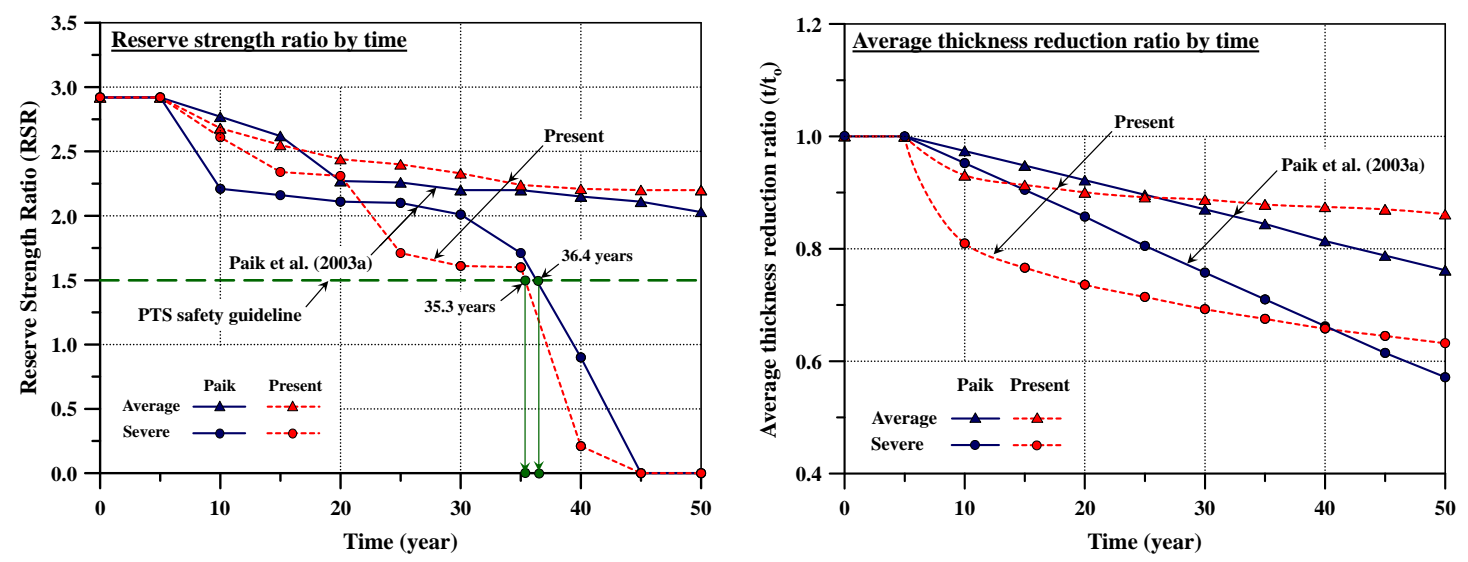

(a) Reserve strength ratio

(b) Structural thickness reduction ratio

Figure 11. Structural performance against time.

\section{CONCLUSIONS}

From the present study, we have obtained results regarding time-variant corrosion model as well as the safety of corroded offshore fixed jacket structures. The time-variant corrosion wastage models for subsea gas pipeline were proposed. From the obtained timevariant corrosion wastage model a simple and direct estimation of corrosion behaviour was performed. It was well recognised that pitting was one of the representative phenomena of corrosion type. It was natural for corrosion damage to occur in steel structures, i.e., ship, offshore, and subsea structures, as time goes by. In the case of subsea pipeline, maintenance or repair would require severe loss of production and time. In addition, the inspection of subsea pipeline, which was normally performed by pigging tool was a time-consuming and expensive job. In this regard, the time-variant corrosion wastage model for pipeline was needed for the estimation of corrosion damage growth.

In addition, in this study, a nonlinear finite element method was adopted in order to determine the ultimate strength of a corroded platform by quantifying the RSR value. From the results, all of the RSR values for average corrosion condition in both models were higher than the acceptable value. The platform can operate up to 50 years with average corrosion taking place, different to severe corrosion, where the platform was limited to 35 years of life because the RSR was no longer safe beyond that period of time. The thickness reduction played an important role in RSR value. It was observed that the 
trend of RSR decrement depended on the trend of wall thickness reduction. The results were seen clearly when average corrosion was applied to the platform. Finally, we have observed that the average corrosion condition relatively simulated the calm waters of Malaysia where the environmental condition is much safer compared to the North Sea region or the Gulf of Mexico, meaning that different levels of corrosion allowance may lead to saving the construction cost and can be adapted to the offshore jacket structures in Malaysian waters. To get a very clear understanding of this matter and for validation purposes, a few more platforms will be analysed with the same approach and method. Based on the present study, reliability analysis will be conducted in order to determine the reliability index which was very crucial to examine the probability of platform failure.

\section{ACKNOWLEDGEMENTS}

This study was undertaken at Ocean and Ship Technology (OST) under Deepwater Technology Mission Oriented Research at Universiti Teknologi PETRONAS. This research was supported by the Technology Innovation Program (Grant No.: 10053121 and 10051279) funded by the Ministry of Trade, Industry \& Energy (MI, Korea) and YUTP Grant (0153AA-E60, Malaysia). The authors would also like to thank for the great support of POSTECH, POSCO, and Daewoo E\&C, Republic of Korea. Some part of this paper was presented in the International Conference on Ocean, Mechanical and Aerospace for Scientists and Engineers (OMAse 2016), 7-8 November 2016, Universiti Malaysia Terengganu, Kuala Terengganu, Malaysia.

\section{REFERENCES}

[1] Misra SC. Design Principles of Ships and Marine Structures: CRC Press; 2015.

[2] Potty NS, Akram MKBM. Structural integrity management for fixed offshore platforms in Malaysia. International Journal of Civil and Environmental Engineering. 2009;3(10):434-42.

[3] Soom E, Husain M, Zaki N, Nor M, Ayob M, Najafian G. Global Ultimate Strength Assessment (GUSA) for Lifetime Extension of Ageing Offshore Structures. The Twenty-fifth International Ocean and Polar Engineering Conference: International Society of Offshore and Polar Engineers; 2015.

[4] Nizamani Z. Environmental load factors and system strength evaluation of offshore jacket platforms: Springer; 2015.

[5] Cossa NJ, Potty NS, Idrus AB, Hamid MFA, Nizamani Z. Reliability analysis of jacket platforms in Malaysia-environmental load factors. Research Journal of Applied Sciences, Engineering and Technology. 2012;4:3544-51.

[6] Kurian V, Goh SS, Wahab MMA. Reliability Assessment Model for Aging Jacket Structures in Malaysian Waters; 2014.

[7] Bai Y, Kim Y, Yan H-b, Song X-f, Jiang H. Reassessment of the jacket structure due to uniform corrosion damage. Ships and Offshore Structures. 2016;11:10512.

[8] Melchers RE. The effect of corrosion on the structural reliability of steel offshore structures. Corrosion science. 2005;47:2391-410.

[9] Wang Y, Wharton JA, Shenoi RA. Ultimate strength analysis of aged steel-plated structures exposed to marine corrosion damage: A review. Corrosion Science. 2014;86:42-60. 
[10] Larin O, Barkanov E, Vodka O. Prediction of reliability of the corroded pipeline considering the randomness of corrosion damage and its stochastic growth. Engineering Failure Analysis. 2016;66:60-71.

[11] Dong W, Moan T, Gao Z. Fatigue reliability analysis of the jacket support structure for offshore wind turbine considering the effect of corrosion and inspection. Reliability Engineering \& System Safety. 2012;106:11-27.

[12] Paik JK, Lee JM, Hwang JS, Park YI. A time-dependent corrosion wastage model for the structures of single-and double-hull tankers and FSOs and FPSOs. Marine Technology. 2003;40:201-17.

[13] Oo TZ. Critical Success Factors for Application of BIM for Singapore Architectural Firms: Heriot-Watt University School of the Built Environment; 2014.

[14] PETRONAS. Pipeline inspection report. Kuala Lumpur, Malaysia; 2011.

[15] Paik JK, Kim DK. Advanced method for the development of an empirical model to predict time-dependent corrosion wastage. Corrosion Science. 2012;63:51-8.

[16] Qin S, Cui W. Effect of corrosion models on the time-dependent reliability of steel plated elements. Marine Structures. 2003;16:15-34.

[17] Soares CG, Garbatov Y, Zayed A, Wang G. Non-linear corrosion model for immersed steel plates accounting for environmental factors. Transactions of the Society of Naval Architects and Marine Engineers. 2005;113:306-22.

[18] Ossai CI, Boswell B, Davies IJ. Predictive modelling of internal pitting corrosion of aged non-piggable pipelines. Journal of the Electrochemical Society. 2015;162:C251-C9.

[19] Ossai CI, Boswell B, Davies I. Markov chain modelling for time evolution of internal pitting corrosion distribution of oil and gas pipelines. Engineering Failure Analysis. 2016;60:209-28.

[20] Melchers R. Probabilistic modelling of immersion corrosion of steels in marine waters. Proceedings of Offshore Mechanics and Arctic Engineering Conference; 2001.

[21] Melchers R. Mathematical modelling of the diffusion controlled phase in marine immersion corrosion of mild steel. Corrosion Science. 2003;45:923-40.

[22] Melchers R. Modeling of marine immersion corrosion for mild and low-alloy steels_-Part 1: Phenomenological model. Corrosion. 2003;59:319-34.

[23] Melchers RE. Development of new applied models for steel corrosion in marine applications including shipping. Ships and Offshore Structures. 2008;3:135-44.

[24] Paik JK, Thayamballi AK, Melchers RE. Recent advances in corrosion assessment and management for ships and offshore structures. HIPER 06: 5th International Conference on High-performance Marine Vehicles: Australian Maritime College; 2006. p. 225.

[25] Mohd MH, Kim DK, Kim DW, Paik JK. A time-variant corrosion wastage model for subsea gas pipelines. Ships and Offshore Structures. 2014;9:161-76.

[26] Caleyo F, Velázquez J, Valor A, Hallen J. Probability distribution of pitting corrosion depth and rate in underground pipelines: A Monte Carlo study. Corrosion Science. 2009;51:1925-34.

[27] Chaves IA, Melchers RE. Pitting corrosion in pipeline steel weld zones. Corrosion Science. 2011;53:4026-32.

[28] Bazán FAV, Beck AT. Stochastic process corrosion growth models for pipeline reliability. Corrosion Science. 2013;74:50-8. 
[29] Kim DK, Park DK, Park DH, Kim HB, Kim BJ, Seo JK, et al. Effect of corrosion on the ultimate strength of double hull oil tankers-Part I: hull girders. Structural Engineering and Mechanics. 2012;42:531-49.

[30] Kim DK, Park DK, Park DH, Kim HB, Kim BJ, Seo JK, et al. Effect of corrosion on the ultimate strength of double hull oil tankers-Part II: hull girders. Structural Engineering and Mechanics. 2012;42:531-49.

[31] Kim DK, Kim BJ, Seo JK, Kim HB, Zhang X, Paik JK. Time-dependent residual ultimate longitudinal strength-grounding damage index (RD) diagram. Ocean Engineering. 2014;76:163-71.

[32] Kim DK, Kim HB, Zhang X, Li CG, Paik JK. Ultimate strength performance of tankers associated with industry corrosion addition practices. International Journal of Naval Architecture and Ocean Engineering. 2014;6:507-28.

[33] Kim D, Kim S, Kim H, Zhang X, Li C, Paik J. Ultimate strength performance of bulk carriers with various corrosion additions. Ships and Offshore Structures. 2015;10:59-78.

[34] Kim DK, Park DK, Park DH, Kim HB, Kim BJ, Seo JK, et al. Time-dependent corrosion wastage effect on the ultimate strength performance of FPSOs. Arabian Journal for Science and Engineering. 2014;39:7673-90.

[35] Mohd MH, Paik JK. Investigation of the corrosion progress characteristics of offshore subsea oil well tubes. Corrosion Science. 2013;67:130-41.

[36] Paik JK, Kim SK, Lee SK. Probabilistic corrosion rate estimation model for longitudinal strength members of bulk carriers. Ocean Engineering. 1998;25:83760.

[37] Park DK, Kim DK, Seo JK, Kim BJ, Ha YC, Paik JK. Operability of non-ice class aged ships in the Arctic Ocean-part II: Accidental limit state approach. Ocean Engineering. 2015;102:206-15.

[38] Park DK, Kim DK, Seo JK, Kim BJ, Ha YC, Paik JK. Operability of non-ice class aged ships in the Arctic Ocean-part I: Accidental limit state approach. Ocean Engineering. 2015;102:206-15.

[39] Raheem SEA. Nonlinear response of fixed jacket offshore platform under structural and wave loads. Coupled Systems Mechanics. 2013;2:111-26.

[40] Zaghloul H. Calibration of Deterministic Parameters: Reassessment of Offshore Platforms in the Arabian Gulf: Universal-Publishers; 2011.

[41] Nelson A, Sanderson D, Thurlbeck S. Effect of platform robustness on inspection planning: HSE Books; 2004.

[42] Energy W. Perfect Interaction.

[43] Kim DK, Park DK, Kim HB, Seo JK, Kim BJ, Paik JK, et al. The necessity of applying the common corrosion addition rule to container ships in terms of ultimate longitudinal strength. Ocean Engineering. 2012;49:43-55.

[44] Paik JK, Thayamballi AK. Ultimate limit state design of steel-plated structures: John Wiley \& Sons; 2003. 


\section{APPENDIX}

For one year of exposure time after breakdown of the coating $\left(T_{\mathbf{e}}\right)$

$$
\begin{gathered}
t_{r(\text { measured })}=\left\{\begin{array}{lll}
0.749 \cdot(T-1)^{0.391} & \text { for Mean } & \left(R^{2}=0.993\right) \\
1.742 \cdot(T-1)^{0.212} & \text { for Mean }+ \text { S.D. } & \left(R^{2}=0.996\right) \\
2.842 \cdot(T-1)^{0.137} & \text { for Mean } 2 S . D . & \left(R^{2}=0.972\right) \\
4.178 \cdot(T-1)^{0.064} & \text { for } 95 \% \text { \& above } & \left(R^{2}=0.984\right)
\end{array}\right. \\
t_{r \text { (approximate })}=\left\{\begin{array}{lll}
0.748 \cdot(T-1)^{0.392} & \text { for Mean } & \left(R^{2}=0.999\right) \\
1.717 \cdot(T-1)^{0.224} & \text { for Mean }+ \text { S.D. } & \left(R^{2}=0.988\right) \\
2.812 \cdot(T-1)^{0.141} & \text { for Mean }+2 S . D . & \left(R^{2}=0.971\right) \\
4.176 \cdot(T-1)^{0.065} & \text { for 95\% \& above }\left(R^{2}=0.984\right)
\end{array}\right.
\end{gathered}
$$

For two years of exposure time after breakdown of the coating $\left(\mathbf{T}_{\mathrm{e}}\right)$

$$
\begin{array}{r}
t_{r(\text { measured })}=\left\{\begin{array}{lll}
0.834 \cdot(T-2)^{0.362} & \text { for Mean } & \left(R^{2}=0.992\right) \\
1.845 \cdot(T-2)^{0.197} & \text { for Mean }+ \text { S.D. } . & \left(R^{2}=0.997\right) \\
2.939 \cdot(T-2)^{0.128} & \text { for Mean } 2 S . D . & \left(R^{2}=0.972\right) \\
4.239 \cdot(T-2)^{0.061} & \text { for } 95 \% \text { \& above } & \left(R^{2}=0.984\right)
\end{array}\right. \\
t_{r(\text { approximate })}=\left\{\begin{array}{lll}
0.832 \cdot(T-2)^{0.363} & \text { for Mean } & \left(R^{2}=0.999\right) \\
1.821 \cdot(T-2)^{0.208} & \text { for Mean }+ \text { S.D. } & \left(R^{2}=0.989\right) \\
2.911 \cdot(T-2)^{0.132} & \text { for Mean }+2 S . D . & \left(R^{2}=0.971\right) \\
4.237 \cdot(T-2)^{0.061} & \text { for } 95 \% \text { \& above } & \left(R^{2}=0.984\right)
\end{array}\right.
\end{array}
$$

For three years of exposure time after breakdown of the coating $\left(\mathbf{T}_{\mathrm{e}}\right)$

$$
\begin{gathered}
t_{r(\text { measured })}=\left\{\begin{array}{lll}
0.929 \cdot(T-3)^{0.332} & \text { for Mean } & \left(R^{2}=0.992\right) \\
1.955 \cdot(T-3)^{0.181} & \text { for Mean }+ \text { S.D. } . & \left(R^{2}=0.997\right) \\
3.041 \cdot(T-3)^{0.119} & \text { for Mean }+2 S . D . & \left(R^{2}=0.973\right) \\
4.304 \cdot(T-3)^{0.057} & \text { for } 95 \% \text { \& above } & \left(R^{2}=0.984\right)
\end{array}\right. \\
t_{r \text { (approximate })}=\left\{\begin{array}{lll}
0.926 \cdot(T-3)^{0.333} & \text { for Mean } \quad\left(R^{2}=0.999\right) \\
1.933 \cdot(T-3)^{0.192} & \text { for Mean }+ \text { S.D. } . & \left(R^{2}=0.990\right) \\
3.015 \cdot(T-3)^{0.123} & \text { for Mean }+2 S . D . & \left(R^{2}=0.972\right) \\
4.300 \cdot(T-3)^{0.057} & \text { for 95\% \& above }\left(R^{2}=0.985\right)
\end{array}\right.
\end{gathered}
$$

For four years of exposure time after breakdown of the coating ( Te)

$$
\begin{aligned}
t_{r \text { (measured })} & =\left\{\begin{array}{lll}
1.037 \cdot(T-4)^{0.301} & \text { for Mean } & \left(R^{2}=0.991\right) \\
2.074 \cdot(T-4)^{0.164} & \text { for Mean }+ \text { S.D. } & \left(R^{2}=0.997\right) \\
3.151 \cdot(T-4)^{0.110} & \text { for Mean }+2 S . D . & \left(R^{2}=0.974\right) \\
4.372 \cdot(T-4)^{0.053} & \text { for 95\% \& above } & \left(R^{2}=0.985\right)
\end{array}\right. \\
t_{r \text { (approximate })}= & \begin{array}{lll}
1.034 \cdot(T-4)^{0.302} & \text { for Mean } & \left(R^{2}=0.999\right) \\
2.054 \cdot(T-4)^{0.175} & \text { for Mean }+ \text { S.D. } & \left(R^{2}=0.991\right) \\
3.127 \cdot(T-4)^{0.113} & \text { for Mean }+2 S . D . & \left(R^{2}=0.973\right) \\
4.368 \cdot(T-4)^{0.054} & \text { for 95\% \& above } & \left(R^{2}=0.985\right)
\end{array}
\end{aligned}
$$

For five years of exposure time after breakdown of the coating (Te)

$$
\begin{aligned}
& t_{r(\text { measured })}=\left\{\begin{array}{lll}
1.163 \cdot(T-5)^{0.267} & \text { for Mean } & \left(R^{2}=0.989\right) \\
2.206 \cdot(T-5)^{0.146} & \text { for Mean }+ \text { S.D. } & \left(R^{2}=0.998\right) \\
2.777 \cdot(T-5)^{0.197} & \text { for Mean }+2 S . D . & \left(R^{2}=0.999\right) \\
3.948 \cdot(T-5)^{0.122} & \text { for 95\% \& above }\left(R^{2}=0.999\right)
\end{array}\right. \\
& t_{r \text { (approximate })}=\left\{\begin{array}{lll}
1.587 \cdot(T-5)^{0.269} & \text { for Mean } \quad\left(R^{2}=0.998\right) \\
2.189 \cdot(T-5)^{0.157} & \text { for Mean }+ \text { S.D. }\left(R^{2}=0.992\right) \\
3.248 \cdot(T-5)^{0.103} & \text { for Mean }+2 S . D . & \left(R^{2}=0.975\right) \\
4.440 \cdot(T-5)^{0.049} & \text { for 95\% \& above }\left(R^{2}=0.986\right)
\end{array}\right.
\end{aligned}
$$




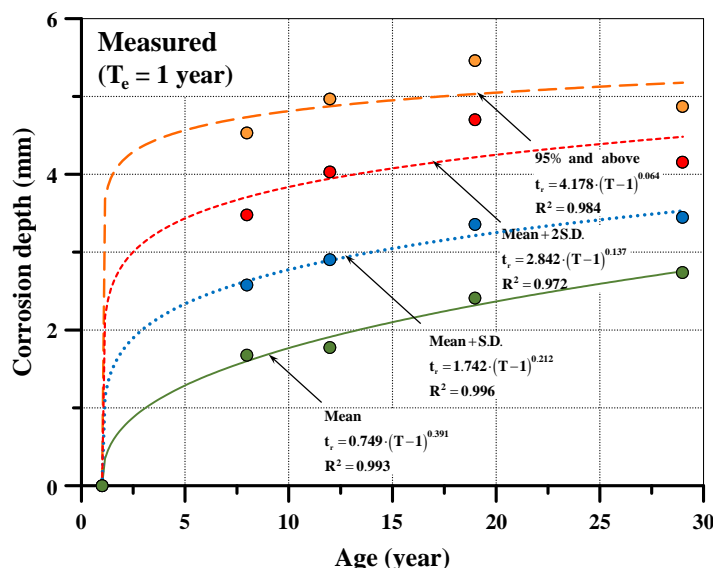

(a) Measure data based model $\left(T_{e}=1\right)$

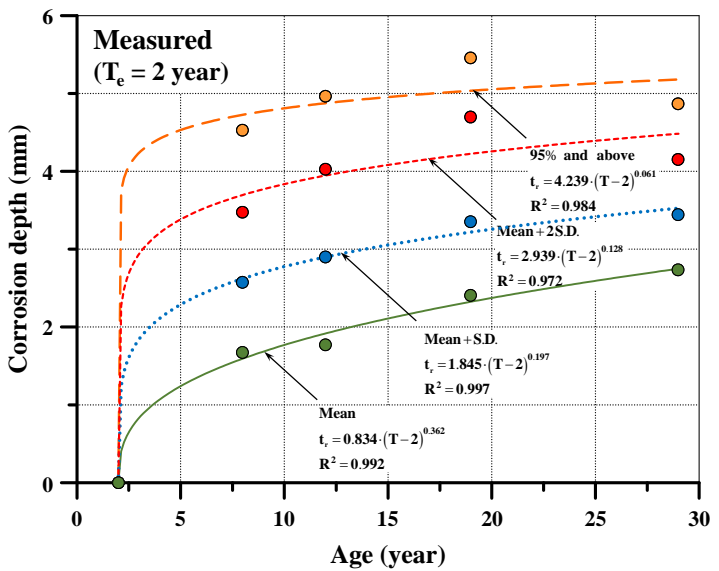

(c) Measure data based model $\left(T_{e}=2\right)$

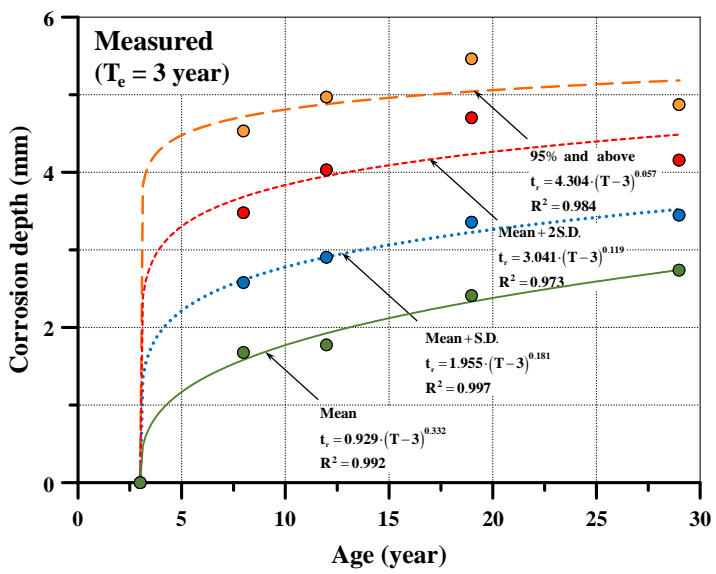

(e) Measure data based model $\left(T_{e}=3\right)$

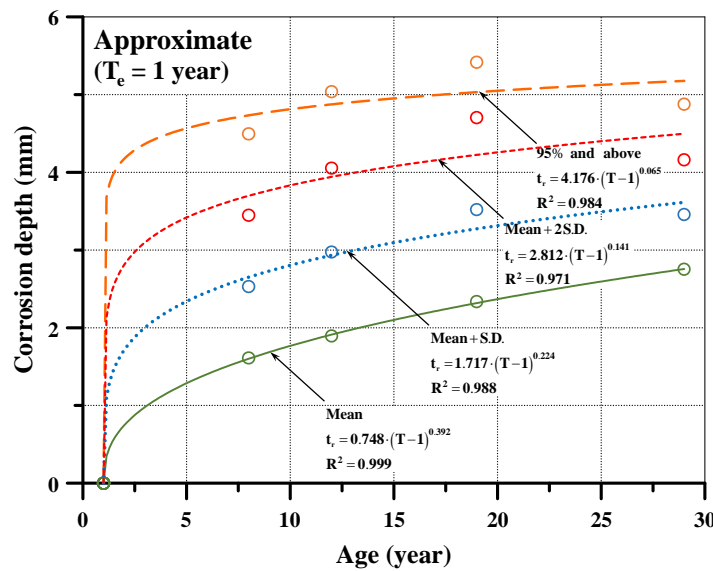

(b) Approximate data based model $\left(T_{e}=1\right)$

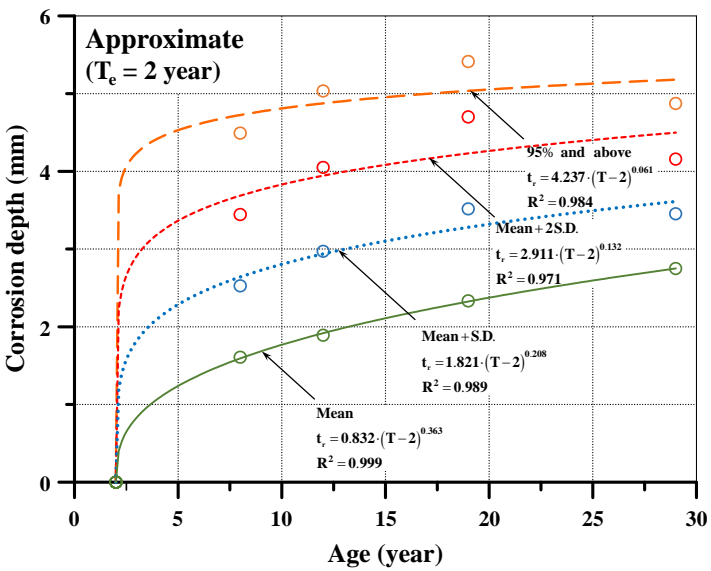

(d) Approximate data based model $\left(T_{e}=2\right)$

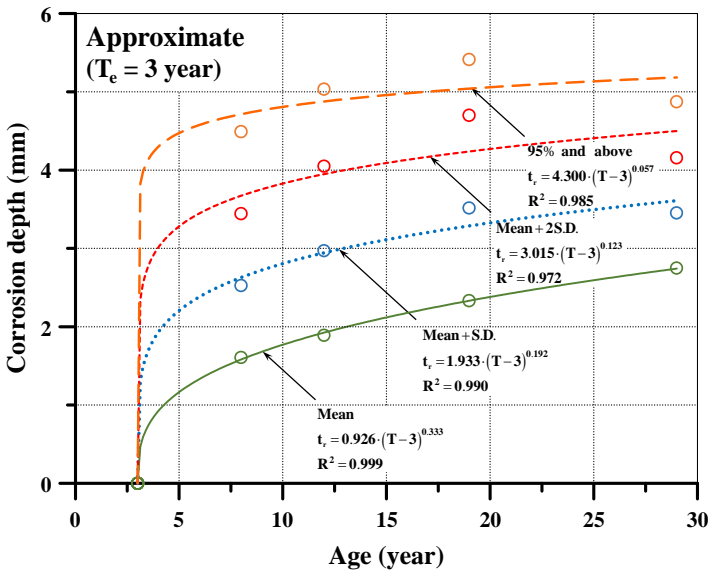

(f) Approximate data based model $\left(T_{e}=3\right)$

Figure A1. Proposed time-variant corrosion wastage model for gas pipeline. 


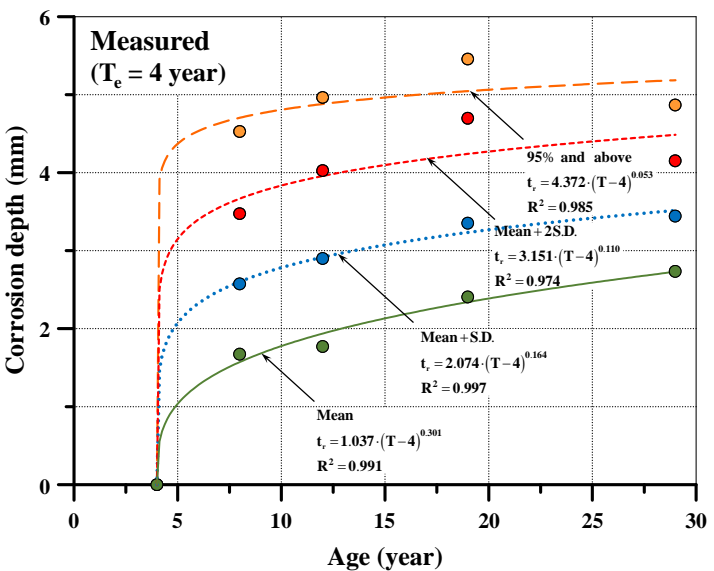

(g) Measure data based model $\left(T_{e}=4\right)$

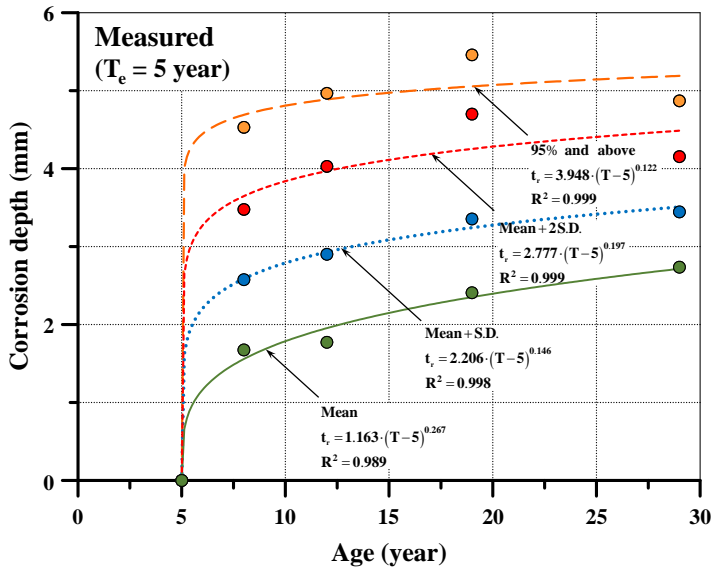

(i) Measure data based model $\left(T_{e}=5\right)$

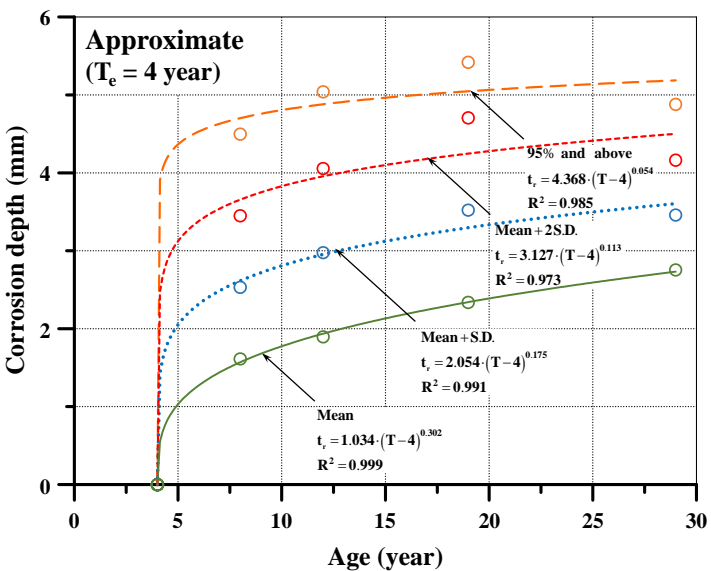

(h) Approximate data based model ( $\left.T_{e}=4\right)$

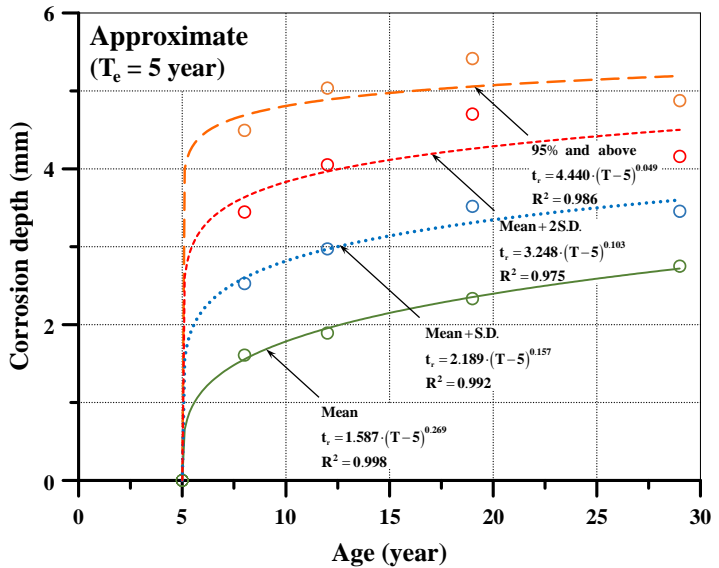

(j) Approximate data based model $\left(T_{e}=5\right)$

(Note: $T_{e}=$ exposure time in years after breakdown of the coating $\left(=T-T_{c}-T_{t}\right)$, $T=$ exposure time in years, $T_{c}=$ coating life in years, $T_{t}=$ duration of transition in years)

Figure A1. Continued. 
ABBREVIATION

\begin{tabular}{|c|c|c|c|}
\hline Abbreviation & Description & Abbreviation & Description \\
\hline $\mathrm{B} / \mathrm{S}-\mathrm{H}$ & $\begin{array}{l}\text { Bottom shell plating } \\
\text { (segregated ballast tank) }\end{array}$ & SSLB(W) & $\begin{array}{l}\text { Side shell longitudinals in } \\
\text { ballast tank, web }\end{array}$ \\
\hline A/B-H & $\begin{array}{l}\text { Deck plating (segregated } \\
\text { ballast tank) }\end{array}$ & $\operatorname{SSLB}(F)$ & $\begin{array}{l}\text { Side shell longitudinals in } \\
\text { ballast tank, flange }\end{array}$ \\
\hline $\mathrm{A} / \mathrm{B}-\mathrm{V}$ & $\begin{array}{l}\text { Side shell plating above } \\
\text { draft line (segregated } \\
\text { ballast tank) }\end{array}$ & $\operatorname{LBLB}(\mathrm{W})$ & $\begin{array}{l}\text { Longitudinal bulkhead } \\
\text { longitudinals in ballast } \\
\text { tank, web }\end{array}$ \\
\hline $\mathrm{B} / \mathrm{S}-\mathrm{V}$ & $\begin{array}{l}\text { Side shell plating below } \\
\text { draft line (segregated } \\
\text { ballast tank) }\end{array}$ & $\operatorname{LBLB}(\mathrm{F})$ & $\begin{array}{l}\text { Longitudinal bulkhead } \\
\text { longitudinals in ballast } \\
\text { tank, flange }\end{array}$ \\
\hline BLGB & $\begin{array}{l}\text { Bilge plating (segregated } \\
\text { ballast tank) }\end{array}$ & $\operatorname{BSLC}(\mathrm{W})$ & $\begin{array}{l}\text { Bottom shell longitudinals } \\
\text { in cargo oil tank, web }\end{array}$ \\
\hline $\mathrm{O} / \mathrm{B}-\mathrm{V}$ & $\begin{array}{l}\text { Longitudinal bulkhead } \\
\text { plating (segregated bal- } \\
\text { last tank) }\end{array}$ & $\mathrm{BSLC}(\mathrm{F})$ & $\begin{array}{l}\text { Bottom shell longitudinals } \\
\text { in cargo oil tank, flange }\end{array}$ \\
\hline $\mathrm{B} / \mathrm{B}-\mathrm{H}$ & $\begin{array}{l}\text { Stringer plating } \\
\text { (segregated ballast tank) }\end{array}$ & $\operatorname{DLC}(\mathrm{W})$ & $\begin{array}{l}\text { Deck longitudinals in } \\
\text { cargo oil tank, web }\end{array}$ \\
\hline $\mathrm{O} / \mathrm{S}-\mathrm{H}$ & $\begin{array}{l}\text { Bottom shell plating } \\
\text { (cargo oil tank) }\end{array}$ & $\operatorname{DLC}(\mathrm{F})$ & $\begin{array}{l}\text { Deck longitudinals in } \\
\text { cargo oil tank, flange }\end{array}$ \\
\hline A/O-H & $\begin{array}{l}\text { Deck plating (cargo oil } \\
\text { tank) }\end{array}$ & $\operatorname{SSLC}(\mathrm{W})$ & $\begin{array}{l}\text { Side shell longitudinals in } \\
\text { cargo oil tank, web }\end{array}$ \\
\hline $\mathrm{A} / \mathrm{O}-\mathrm{V}$ & $\begin{array}{l}\text { Side shell plating above } \\
\text { draft line (cargo oil tank) }\end{array}$ & $\operatorname{SSLC}(\mathrm{F})$ & $\begin{array}{l}\text { Side shell longitudinals in } \\
\text { cargo oil tank, flange }\end{array}$ \\
\hline $\mathrm{O} / \mathrm{S}-\mathrm{V}$ & $\begin{array}{l}\text { Side shell plating below } \\
\text { draft line (cargo oil tank) }\end{array}$ & $\operatorname{LBLC}(\mathrm{W})$ & $\begin{array}{l}\text { Longitudinal bulkhead } \\
\text { longitudinals in cargo oil } \\
\text { tank, web }\end{array}$ \\
\hline BLGC & $\begin{array}{l}\text { Bilge plating (cargo oil } \\
\text { tank) }\end{array}$ & $\mathrm{LBLC}(\mathrm{F})$ & $\begin{array}{l}\text { Longitudinal bulkhead } \\
\text { longitudinals in cargo oil } \\
\text { tank, flange }\end{array}$ \\
\hline $\mathrm{O} / \mathrm{O}-\mathrm{V}$ & $\begin{array}{l}\text { Longitudinal bulkhead } \\
\text { plating (cargo oil tank) }\end{array}$ & $\mathrm{BGLC}(\mathrm{W})$ & $\begin{array}{l}\text { Bottom girder } \\
\text { longitudinals in cargo oil } \\
\text { tank, web }\end{array}$ \\
\hline $\mathrm{O} / \mathrm{O}-\mathrm{H}$ & $\begin{array}{l}\text { Stringer plating (cargo oil } \\
\text { tank) }\end{array}$ & BGLC $(F)$ & $\begin{array}{l}\text { Bottom girder } \\
\text { longitudinals in cargo oil } \\
\text { tank, flange }\end{array}$ \\
\hline $\mathrm{BSLB}(\mathrm{W})$ & $\begin{array}{l}\text { Bottom shell } \\
\text { longitudinals in ballast } \\
\text { tank, web }\end{array}$ & DGLC(W) & $\begin{array}{l}\text { Deck girder longitudinals } \\
\text { in cargo oil tank, web }\end{array}$ \\
\hline $\mathrm{BSLB}(\mathrm{F})$ & $\begin{array}{l}\text { Bottom shell } \\
\text { longitudinals in ballast } \\
\text { tank, flange }\end{array}$ & DGLC $(F)$ & $\begin{array}{l}\text { Deck girder longitudinals } \\
\text { in cargo oil tank, flange }\end{array}$ \\
\hline $\mathrm{DLB}(\mathrm{W})$ & $\begin{array}{l}\text { Deck longitudinals in } \\
\text { ballast tank, web }\end{array}$ & SSTLC(W) & $\begin{array}{l}\text { Side stringer longitudinals } \\
\text { in cargo oil tank, web }\end{array}$ \\
\hline
\end{tabular}

